Article

\title{
Settlements and Urban Morphological Quality in Landscape Planning-Analytical Models and Regulating Tools in the Landscape Plan of Regione Toscana
}

\author{
Massimo Carta *, Maria Rita Gisotti and Fabio Lucchesi
}

check for

updates

Citation: Carta, M.; Gisotti, M.R.;

Lucchesi, F. Settlements and Urban Morphological Quality in Landscape Planning-Analytical Models and Regulating Tools in the Landscape Plan of Regione Toscana.

Sustainability 2022, 14, 1851. https:// doi.org/10.3390/su14031851

Academic Editors: Anna Maria Colavitti, Chiara Garau and Sergio Serra

Received: 31 December 2021

Accepted: 3 February 2022

Published: 6 February 2022

Publisher's Note: MDPI stays neutral with regard to jurisdictional claims in published maps and institutional affiliations.

Copyright: (c) 2022 by the authors. Licensee MDPI, Basel, Switzerland. This article is an open access article distributed under the terms and conditions of the Creative Commons Attribution (CC BY) license (https:// creativecommons.org/licenses/by/ $4.0 /)$.

\author{
Department of Architecture DIDA, University of Florence, Via della Mattonaia 8, 50121 Florence, Italy; \\ mariarita.gisotti@unifi.it (M.R.G.); fabio.lucchesi@unifi.it (F.L.) \\ * Correspondence: massimo.carta@unifi.it; Tel.: +39-055-2755410
}

\begin{abstract}
Settlement and urban landscape quality is a vast field of research, ranging from studies on "the shape of the city" to studies on functions and services performed by the urban landscape. In Italy, a decisive steering role is entrusted to regional landscape planning, as introduced through the current Code of Cultural Heritage and Landscape. Regional landscape plans define the rules to which all municipal plans must conform. This paper aims to assess the effectiveness with which the general principles and rules regarding settlement and urban landscape quality defined on a regional level through landscape plans are transposed and implemented on a local level through municipal plans. We chose the case study of Regione Toscana, which has a Regional Landscape Plan approved in 2015 (PIT/PPR) that identifies "settlement morphotypes" and "contemporary urbanisation morphotypes" and presents "Guidelines for landscape redevelopment of urbanised fabric in the contemporary city". We examined how the eight municipal plans approved so far are addressed in the PIT/PPR contents. We also conducted a more in-depth study on topics of interest through structured interviews with four designers who were responsible for most of the plans analysed. We also conducted a more in-depth study on topics of interest through structured interviews with several plan designers. The results from the discussion showed some weakness in the PIT/PPR's ability to guide local planning tools to improve urban quality. Additionally, the PIT/PPR's effectiveness appears more evident in the rhetoric of arguments used by local plans than in the results of the transformations that they prefigure.
\end{abstract}

Keywords: landscape governance; municipal plans; settlement and urban morphotypes; landscape plan effectiveness; edge redevelopment

\section{Introduction}

Landscape quality in reference to the city and settlements is an extremely vast field of study referable to various scales, approaches and disciplinary traditions. Within these various meanings, we have chosen to focus on or take into account how this theme is treated in studies on spatial planning, landscape and urban planning; thus, with a particular emphasis on morphological and functional components. Therefore, we have excluded disciplinary traditions related exclusively to the geography, architecture and philosophy of landscape. Regarding the field that we have chosen, in a summary with an inevitable amount of simplification, we can identify two endpoints: one endpoint is studies on landscape quality of settlements (in which landscape is essentially seen as the forma urbis, or 'shape of the city'); the other endpoint is studies on urban landscape quality with particular reference to a set of functions and services performed by the urban landscape.

\subsection{Settlement Landscape Quality (Forma Urbis)}

Studies on the shape of the city can be organised into various approaches.

The first approach is rooted in a series of theories and practices that define urban limitations, which were developed primarily during the massive 19th-century urbanisation 
processes that took place in most European cities. In 1898, Ebenezer Howard was the first to propose the 'garden city' settlement model, in which landscape (understood as a 'natural' and not artificialised space) became an element of control and containment of urban growth. That concept was further developed in planning proposals for the conurbation of London, first by Raymond Unwin in 1929, and then Patrick Abercrombie in 1944 in a more complete form. From that moment until recent times, the use of a green belt took on the role of controlling city growth and was reaffirmed in the Greater London Authority's 2004 London Plan. In many European cities in the mid-to-late 1900s, urban model proposals, which were based on the British experience and a nucleus of theories, clearly delineated a green edge in which "landscape and townscape" [1] are reciprocally defined by a complementary relationship. Examples of these are: the GrünGürtel in Frankfurt and Munich, Anella Verda in Barcelona and Paris's Ceinture Verte envisioned by the Schéma Directeur de la Région Ile-de-France [2]. There are also Italian green belt models: the first one dates back to the early 1900s and includes the 'ring of parks' around the consolidated city of Rome, designed by Marcello Piacentini in 1916. Then came the most intense period of urbanisation in Italy, which included the green belt from the 1979 Development Plan for Milan; in recent years, interventions have included the 'green wall' and 'historical park of the hills' from the 1992 General Regulatory Plan (GRP) of Florence and the "Green Crown" project (2000) that surrounds Turin with an integrated park system.

The second fundamental approach to the forma urbis is typically Italian in style. It began with studies by Saverio Muratori [3] that examined the relationship between historical settlements and natural environments, and then identified 'types' of urban and territorial settlements. We can extract principles and rules from these typifications for a correct design of settlements that are consistent with their historical territorial structures. The theme has significant affinities with the "shape of the territory" that Vittorio Gregotti [4] believed could generate a settlement project. This subject was further developed in studies by Luigi Piccinato [5] on the morphogenetic function of land with respect to historical settlements. Then came Bernardo Secchi's structural approach [6], which is well-represented by plans such as the one for Siena, where the particular morphological conformation of a territory was the ideal opportunity to identify founding settlement principles, with which transformations must be consistent (the same settlement principles described by Pier Paolo Pasolini in his well-known 1974 documentary entitled "Shape of the City" about the town of Orte).

Regarding this first area of study, settlement landscape quality can be defined by morphological criteria (which can be a litmus test for other, even functional, aspects). This depends on the degree of formal completion of a settlement and the recognisability of its boundaries. In recent times, a line of 'morphotypological' studies has been developed in numerous examples of planning, rather than in a large body of literature, including the Regional Landscape Plan of Tuscany, which we discuss in detail in this paper. Conversely, numerous theoretical studies have been produced in reference to both the urban edge and containment of land consumption [7]. Ahani and Dadashpoor [8] proposed a systematisation of various categories into which this line of studies could be organised. The first category is urban growth containment policies based on planning interventions (UGCPI), which can, in turn, be divided into three types of approaches: those that update the use of green belts, namely non-building areas such as open green spaces, forests or arable lands [9]; those based on the delineation of urban growth boundaries, namely a "formal line for separating an urban environment from the open lands around it" [10]; an approach in which the 'line' is not a real perimeter but an external limit within which the implementation costs for infrastructures and services fall entirely to the subjects responsible for the transformation intervention [11]. The second is urban growth containment policies based on financial interventions (UGCFI), which is based on the application of taxes and fines for expansion into specific areas [12] or the transfer of development rights [13].

Finally, in the literature on urban edge, there is an important line of studies focused on the role of agricultural spaces in the creation of new settlement models [14-16], which 
are based on the valorisation agricultural multifunctionality $[17,18]$, variety of ecosystem services [19] and opportunities of morphological redevelopment that agricultural areas can offer to settlements [20].

\subsection{Urban Landscape Quality}

Studies on urban landscape quality belong to other disciplinary traditions. Golkar [21,22] identified four approaches to the subject throughout history: (1) artistic, (2) functional, (3) perceptual/contextual and (4) sustainable. Keshtkaran [23] then created outlines for these approaches. We now propose a critical reading of the four approaches, highlighting how the concepts of urban landscape and its quality become increasing more complex with each approach.

The artistic approach began in the late 1800s with the studies of Camillo Sitte [24]. Urban landscape quality is pursued from both decorative interventions to façades and through the revival of a series of spatial relationships between serial construction, monumental emergencies and open spaces (with particular attention to the piazza and its controlling role in urban fabrics), inferred from historical models. The nature of urban quality is essentially aesthetic.

The functional approach is well represented by the work of Le Corbusier. In his progressive approach, urban landscape quality depends on the efficiency of the city and is pursued through standardised and replicable interventions. Therefore, it is a concept in which the element of function is added to the element of aesthetic, albeit in a radically different way with respect to the preceding tradition.

The perceptual/contextual approach began in the 1960s with studies by Donal Appleyard and Kevin Lynch [25], to which we must add two fundamental contributions by Gordon Cullen [26] and Jane Jacobs [27]. The relative objectivity of the previous two approaches has been replaced by a subjective point of view on urban landscape. Its quality is functional with such characteristics as 'legibility' and 'figurability', which derive from the perceptive ability that the subject exercises on the urban context. Consequently, urban landscape is a "social-spatial structure" [23] (p.146). Urban landscape quality is a socio-cultural and intersubjective concept.

The fourth approach focuses on sustainability as the central concept of urban landscape quality, and its main exponents are Ian MacHarg [27] and Peter Calthorpe [28]. An emphasis is placed on the ecological performance that the city is able to provide. With these studies, urban landscape quality returns to being a functional concept. However, unlike functionalism in the early 1900s, when humans were the one and only beneficiary of design actions, in this more recent acceptation, human presence is seen increasingly as only one of many possible expressions of "living being" within the city $[29,30]$. Therefore, urban landscape quality refers to a wider spectrum than users or 'inhabitants', and its ecological and environmental complexity becomes one of its essential elements. Returning to Keshtkaran's research [23] (p. 146), urban landscape is a "sustainable socio-spatial structure".

In the contemporary disciplinary literature, the field of study described here has developed in the direction of conceiving landscape (including urban and suburban landscape) as a "place for sustainability" [31] (p.3), [32]. In this context, through a perspective on the city that we can define as 'landscape', the idea of sustainability "is moving away from being viewed as a specialised type of landscape architectural practice, focused exclusively on ecological concerns, toward a more mainstream concern for all landscape architecture projects" [33] (p.3).

Moreover, a notable amount of literature has developed on what could be considered effective indicators to describe the overall quality of urban landscape, including an assessment of its sustainability. According to Amin [34] (p.105), the parameters to be considered are safety, health, and efficiency, as well as visual and cultural appeal. D'Onofrio and Sargolini, based on studies by Amin and Cocci Grifoni, formulated an idea of urban landscape as a "'complex indicator' of urban sustainability and quality of life of city inhabitants" [35] (p.11). From this, they identified three large "families" in which to allocate 
quality and sustainability indicators of the urban landscape present in European research and studies: "distinctive and pleasant", regarding the presence of both non-artificialised components and collective identification elements; "efficient and nice", regarding urban metabolisms; "clean and healthy", regarding environmental quality and safety (ibidem, p. 39). Gavrilidis et al. [36] integrated economic, social and environmental indicators of urban landscape with aesthetic-perceptive parameters that reveal inhabitant satisfaction within a specific environment.

This idea of urban landscape quality as an indicator of the overall quality of a location is echoed in the 2000 European Landscape Convention (ELC). As we know, the ELC has contributed substantially to overcoming a conception of landscape as exclusively monumental and aesthetic-perceptive by including natural, rural, urban and peri-urban areas, as well as everyday or degraded landscapes [37] (art. 2). The convention also highlights landscape multifunctionality, which "has an important public interest role in the cultural, ecological, environmental and social fields", "is an important part of the quality of life for people everywhere" and "is a key element of individual and social wellbeing" (ibidem, preamble). According to the ELC, landscape is the living environment of populations and, with reference to urban landscape, becomes a significant value that is not only morphological but also functional (adequacy of services and public spaces, or the mixité) and environmental (adequacy of environmental features). Moreover, it is due to these considerations that the ELC asks to "integrate landscape into its regional and town planning policies and in its cultural, environmental, agricultural, social and economic policies, as well as in any other policies with possible direct or indirect impact on landscape" (ibidem, art. 5, par. d). In the past two years, the pandemic has contributed to reinforcing an acceptation regarding urban landscape quality that is strongly linked to accessibility and proximity to common goods, essential services and natural elements, thus highlighting its interpretation of public space.

\subsection{Settlement and Urban Quality in Landscape Planning}

On an operational level, the themes discussed so far have been dealt with on both an urban project scale and a territorial and urban planning scale. In the latter area, a decisive steering role regarding settlement and urban landscape quality in Italy is entrusted to regional landscape planning. Landscape plans, which have been introduced through the current Code of Cultural Heritage and Landscape [38], are superordinate to all other plans and programmes that act on regional territories and define the rules to which all municipal plans must conform.

The objective of this paper is to assess the effectiveness with which general principles and rules regarding settlement and urban landscape quality, defined on a regional level through landscape plans established by the Italian legal system, are transposed and implemented on a local level in municipal plans.

In particular, the paper will assess, with specific reference to planning in Tuscany, if and in what measure its Regional Landscape Plan is effective with respect to these objectives:

- The improvement in landscape quality of settlements through the regulation of the forma urbis and its edge (by both 'restoring' certain identifying characteristics of settlement landscape and containing new urbanisation);

- The improvement in urban landscape quality regarding both the management of building transformations of existing settlements and prefiguration of future urban transformations.

\subsection{Structure and Contents of the Paper}

The paper is structured as follows: in Section 2 (Materials), we present a summary of the tools and methods used to achieve the quality of settlements and urban landscape in Italian landscape planning. Then, we present the case study of Regione Toscana, which has a Regional Landscape Plan (detailed information is available in Supplementary Materials) that was approved in 2015 (called Regional Territorial Plan with the value of Regional Landscape Plan, PIT/PPR), which saw the collaboration of all the authors of this article from the begin- 
ning. In the PIT, the topic of settlement and urban landscape is treated in the so called "third structural invariant", which identifies two reference scales, two analytical-design devices ("settlement morphotypes" and "contemporary urbanisation morphotypes") and another tool called "Guidelines for landscape redevelopment of urbanised fabric in the contemporary city". In Section 3 (Methods), we present the methodology used to assess the regulatory effectiveness of the Plan regarding settlement quality and urban landscape. To this end, we conducted an examination of municipal planning materials produced in eight cases (the only cases as of November 2021) in which drafting methods were completely consistent with the PIT/PPR and Tuscan Regional Law 65/2014 "Regulations for territorial government" (LR 65/2014). We then interviewed several designers of the examined plans, asking them for an overall assessment of the PIT/PPR's effectiveness in guiding the quality of settlements and regional urban landscapes. The results of our municipal plan examination and interviews with municipal plan designers are illustrated in Section 4 . The discussion (Section 5) highlights how the topic of settlement and urban quality deals with different fields of study and scales of reference. In the case of the PIT, we noted several of the plan's limitations along with its elements of relevant innovation, the latter being mostly on a cultural level. In fact, the plan promotes a new vision and new development scenario for the Tuscan landscape. Finally, our conclusions (Section 6) summarise the paper and indicate some theoretical and empirical developments for the future of such an approach to landscape planning.

\section{Materials}

\subsection{Tools and Methods for Settlement and Urban Quality in Italian Landscape Planning}

In Italy, an important role for the management of urban landscape quality is played by a regional landscape planning tool that has existed for many years. It was first introduced by Law 1497/1939 for the protection of natural beauty, which the Government could use to protect places of exceptional value. Then, in 1985, with the enactment of Law 431 (the "Galasso law"), the landscape plan was officially added to the national planning tools and became mandatory for all regions. For many reasons (Gisotti 2018), that generation of landscape plans was adopted by only a few regions and hardly implemented. In 2004, the landscape plan evolved into the Code of Cultural Heritage and Landscape (D.Lgs 42/2004) [38], which defines quality objectives and specific regulations for the protection, valorisation and redevelopment of the entire regional territory (including urbanised areas), to which municipal urban plans must conform. In fact, in accordance with art. 145 of the Code, the Regional Landscape Plan, which each region is obliged to adopt, has a superordinate role with respect to all other plans and programmes that act on the territory. In this section, we present an overview of the tools and methods employed in Regional Landscape Plans to protect and manage urban landscape.

Before examining the issue, we must say that the control and management chain of urban landscape quality - which is guided by both a Regional Landscape Plan and various municipal urban plans [39] — can be a very dangerous weapon if we consider the limited number of Regional Landscape Plans written in accordance with D.Lgs 42/2004 that have been approved (i.e., the regions of Piemonte, Puglia, Toscana, Friuli-Venezia Giulia as well as Regione Sardegna on the coastline) [40-42]. Consequently, the experience gained in the field of conformity or adjustment to regional and municipal plans appears to be immature and largely experimental.

On a national level, knowledge of these processes is not very systematic or updated. The latest ministerial report published on the state of landscape policies in Italy dates back to 2017 [43] and does not contain a framework of how many or which municipalities in regions with approved landscape plans have adopted their urban plans. To this relative inertia, which inevitably weakens the abovementioned control and management chain of urban landscape quality, the National government does not respond with supplementary investments in terms of analytical or policy documents. While it is true that the Government stresses the centrality of landscape and related policies in the National Landscape 
Charter [44], these are only statements that will remain primarily rhetorical if fundamental preconditions that change the drafting process and plan implementation are not put into effect [45]. Moreover, while ministerial guidelines exist for energy efficiency, improvement of accessibility and reduction in the seismic risk to cultural heritage, guidelines for 'ordinary' or even degraded urban landscape, which the ELC places at the heart of its action, remain marginal or unaddressed. Even in the Policy Act that identifies the Government's policy priorities for the 2021-2023 three-year period [46], this theme is mentioned in only one of the intervention areas (ibidem, 3.1,2).

In the years from approval of the code up to the present, those regions that have adopted a landscape plan have shown a more operational attitude, including a highly articulated treatment of the subject on a design and analytical level. In this regard, we must clarify that a structural approach to landscape has been established $[47,48]$ in the approved plans (and the majority of those adopted), which interprets and describes the various components of landscape, including those regarding settlements, in the cognitive framework. Thus, that component is present under the following sections of these plans: under "settlement layout" in the Sardegna PPR; under "anthropic and historical-cultural structure" in the Puglia PPTR; under "morphological-settlement component" in the Piemonte PPR; under "settlement and infrastructural systems" in the Friuli-Venezia-Giulia PPR; under the third of four "structural invariants" in the Toscana PIT. A specific discipline (containing a regulation with varying degrees of cogency) is associated with each component, which local authorities must respect when adapting or conforming their municipal plans to the Regional Landscape Plan. Legislative specifications regarding urban landscape and settlement quality are implemented in this manner.

In general, landscape plans contain a strategic part that includes: regional landscape projects [49-51]; guidelines or support and steering documents that include plan implementation; and graphic rules [52-54]. These are informative and operational documents based on outlines and the integration of textual and graphic content, which adopt figurative, summarised and 'accessible' codes and evoke the diversity of real situations.

This is the case of Regione Piemonte which, since 2010, has produced rather vast documentation that has been added to the Regional Landscape Plan. This includes two documents regarding "Guidelines for landscape quality of settlements"; one refers to local planning [55] and the other to building design [56]. The first document addresses landscape quality by referencing such aspects as: the environment; the public space system; the morphological relationship between land and settlement; settlement types and historical buildings; and production systems and infrastructures. One topic that receives particular attention is the "urban edge", which concerns decreasing land consumption and increasing the polycentric settlement structure. The second document returns to several of these topics (especially the relationship between buildings and land) and further addresses them on a more appropriate architectural scale. Regione Piemonte has also produced "Guidelines on scenic-perceptive aspects" [57] that focus on the correct inclusion of new buildings in the landscape that is consistent with these values.

The Puglia PPTR also contains many policy papers on the quality of settlements and urban landscape. Among the five regional landscape projects included in the strategic scenario, we should mention the "urban-rural pact" - which aims to improve urban edges by promoting the increased quality of both urbanised territory and its adjacent open spaces-and the "valorisation and integrated redevelopment of coastal landscapes", with indications for the regeneration and redevelopment of settlement fabrics (primarily for tourism) present there. The Puglia PPTR includes guidelines for the "design of landscape and ecologically equipped production areas (APPEA)" [58] and "redevelopment of remote and peri-urban agricultural areas" (linked to the regional "urban-rural pact" project [59]). It also includes more detailed guidelines for the "protection, restoration and intervention regarding dry stone structures in Puglia", "recovery, maintenance and reuse of buildings and rural assets" and "recovery of public buildings in protected natural areas". 


\subsection{Renewal of Legislative and Planning Tools of Regione Toscana}

We now examine the Regional Landscape Plan chosen as the case study for this article: the PIT/PPR of Regione Toscana, which was approved in 2015 [60-64]. However, before we begin, we must briefly discuss the abovementioned territorial government act (LR 65/2014), which, along with the PIT/PPR, forms an integrated provision that was approved in November 2014 and is the second revision of a text first published in 1995.

As we previously mentioned, urban planning laws are of regional competence; however, their procedures and tools must recognise that the Government, through its local superintendencies, has a specific competence in all matters regarding fine arts, archaeology and landscape. We must also point out that the law provides for two forms of planning action by municipal administrations. Firstly, they must define their general principles of sustainable development by drafting a "Structural Plan" (Piano Strutturale, PS), which remains valid indefinitely. Secondly, they must outline their intended actions for the transformation of land use in an "Operational Plan" (Piano Operativo, PO) that is valid for five years, corresponding to the duration of their administrative mandate. Regarding the discussion herein, we must note that LR 65/2014 contains a fundamental new element that obligates the perimeterisation of urbanised territory in municipal structural plans (PS). In other words, all PS must map a limit beyond which "transformations that use unbuilt land for settlement or infrastructural use" (LR 65/2014, art. 4, par. 2) are not permitted for residential use; other uses (the most relevant being infrastructure and production) are permissible only if approved through the consensus of Regione Toscana. This is evidently a measure that aims to contain land consumption. As will likely be made clearer below, the delineation of an urbanised territory perimeter has direct and relevant effects on the possible actions of land-use planning and, therefore, on the effectiveness of actions that influence urban quality improvement. Therefore, it is appropriate to present, albeit briefly, the technical character that the law provides for delineating this perimeter, considering that it is an abstract legal condition regarding land transformability, separating potentially buildable land from that where building transformation is impossible. The limit of urbanised territory also concretely identifies the materiality of the edge as a fundamental element of urban quality. The law asks for recognition of the continuity of built-up lots in the existing territory. Wherever that continuity is interrupted, the urban limit must be drawn (LR 65/2014, art. 4, par. 3). However, it immediately adds that "identification of the perimeter of urbanised territory takes into account urban redevelopment and regeneration strategies (...) where this contributes to improving the design of urban edges" (LR 65/2014, art. 4, par. 4). This oscillation between recognising existing conditions and defining transformation conditions adds a critical element to the clear definition of the role of planning tools for which municipal authorities are responsible. As we pointed out, Structural Plans (PS) have an eminently strategic planning role that guarantees the protection and reproduction of anthropic and environmental resources and the general, non-specific definition of desirable directions for change. The effectiveness of actual transformations of physical space is entrusted to land-use planning tools (Piani Operativi, PO) that contain disciplines for urban transformations and the management of existing building stocks. Entrusting the task of delineating the urbanised territory perimeter to the PS seems to exceed its role as a strategic guideline and invade the field of action of land-use planning, with consequences that will be discussed below in relation to the effects of the application of landscape planning.

\subsection{Pit/Ppr Discipline Aimed at Urban Quality Improvement}

The PIT/PPR of Regione Toscana entrusts the regulation of urban quality to the regulatory treatment of the so-called "Third structural invariant: the polycentric and reticular nature of urban and infrastructural settlement systems". The Plan identifies two intervention scales. On a smaller scale, it deals with issues regarding the regional area and identifies components of the polycentric and reticular structure of urban and infrastructural systems that are typical of settlement patterns in Toscana, defining them as 
"settlement morphotypes". On a larger scale, it proposes a settlement taxonomy based on the post-Second World War period according to the following criteria: (i) location (urban vs. extra-urban); (ii) function (residential vs. non-residential); (iii) building density and aggregation (dense and aggregate vs. rarefied and isolated); (iv) relation between building facades and road alignments (parallel and adherent vs. non-parallel and discontinuous); (v) prevalent building type; (vi) relationship to other fabrics and open territory. This taxonomy identifies sixteen "contemporary urbanisation morphotypes" (cf. Table 1).

Table 1. Contemporary urbanisation morphotypes identified by the PIT/PPR.

\begin{tabular}{llll}
\hline \multicolumn{1}{c}{$\begin{array}{c}\text { Primarily Residential and Mixed } \\
\text { Urban Fabric }\end{array}$} & $\begin{array}{c}\text { Primarily Residential and Mixed } \\
\text { Urban and Extra-Urban Fabric }\end{array}$ & $\begin{array}{c}\text { Primarily Residential and } \\
\text { Mixed Extra-Urban Fabric }\end{array}$ & $\begin{array}{c}\text { Specialised and Industrial } \\
\text { Fabric }\end{array}$ \\
\hline $\begin{array}{l}\text { T.R.1. Fabric with closed or } \\
\text { semi-closed blocks }\end{array}$ & T.R.8 Linear fabric & T.R.10 Inhabited countryside & $\begin{array}{l}\text { T.P.S.1. Fabric with linear } \\
\text { industrial proliferation }\end{array}$ \\
$\begin{array}{l}\text { T.R.2. Fabric with open blocks and } \\
\text { isolated residential lots }\end{array}$ & T.R.9 Reticular or sprawled fabric & T.R.11. Urbanised countryside & $\begin{array}{l}\text { T.P.S.2 Fabric with production- } \\
\text { commercial-business platforms }\end{array}$ \\
$\begin{array}{l}\text { T.R.3. Fabric with open blocks and } \\
\text { primarily residential lots }\end{array}$ & & $\begin{array}{l}\text { T.R.12 Small extra-urban } \\
\text { agglomerated blocks }\end{array}$ & T.P.S.3. Specialised islands \\
T.R.4. Fabric with open blocks and & & & T.P.S.4 Fabric with residential and \\
primarily residential developments & & & tourism-hospitality platforms \\
$\begin{array}{l}\text { T.R.5. Punctiform fabric } \\
\text { T.R.6. Mixed-use fabric }\end{array}$ & & & \\
T.R.7. Fringed fabric & & & \\
\hline
\end{tabular}

\subsubsection{Settlement Morphotypes}

The settlement morphotypes proposed in the PIT/PPR articulate the settlement structure of Toscana, identifying eight distinctive patterns determined by land morphology and hydrological organisation. (cf. Figure 1) The discipline regarding recognition of settlement morphotypes consists of "indications for actions" that express the Plan's vision with respect to a desirable result of transformations defined by plans and programmes that influence territory government. However, there is no identification of either to whom this should be entrusted (i.e., which jurisdiction should implement the discipline of the plan) or which plans and programmes should be involved. These conditions make it difficult to verify the regulatory effectiveness of PIT/PPR indications. To identify which subjects the PIT/PPR deems appropriate for implementation, it seems pertinent to conduct a preliminary exploration of the issues addressed in "indications for actions".

\section{Structural representation of the morphotype}

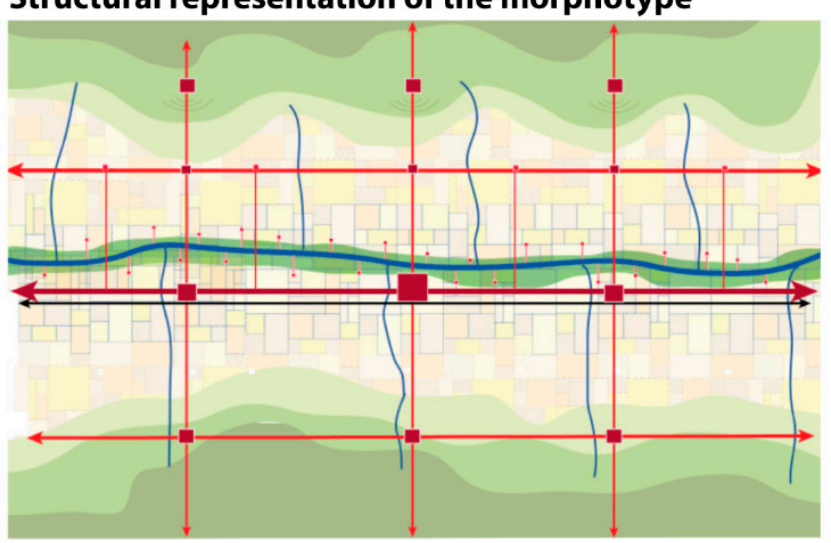

Highlighting of transformation trends

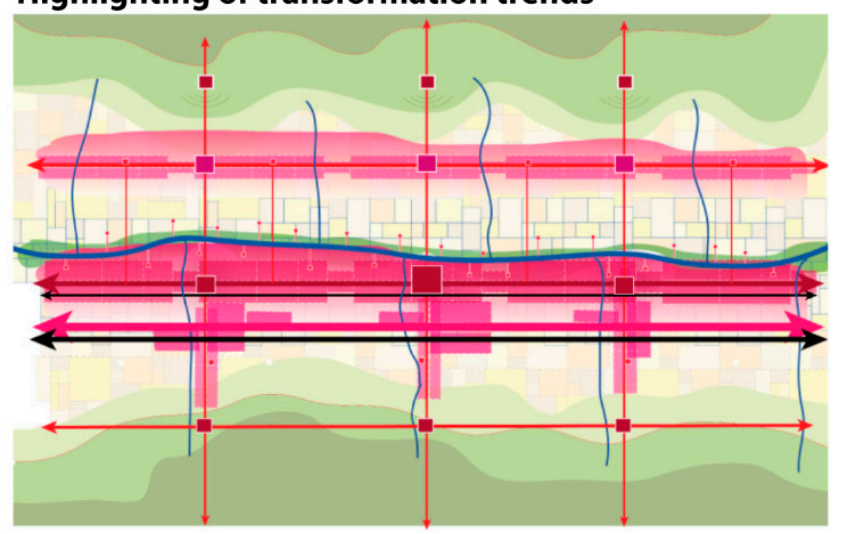

Figure 1. PIT/PPR, an example of the settlement morphotypes: "settlement-linear morphotype".

The first recurring theme in PIT/PPR indications is the limitation of land artificialisation, which means avoiding both new artificialisations where physiographic uniqueness is present and ensuring that openings in linear conurbations remain unbuilt. The second recurring theme evidently regards the regulatory content that is characteristic of municipal 
planning and involves governing of the use and reuse of abandoned buildings. Understandably, the Plan advocates for the recovery and regeneration of unused buildings and areas and encourages minor to major changes of intended use for this purpose. For the third theme, the PIT/PPR focuses its design proposal on developing the governing of infrastructural and settlement patterns in the regional area. This focus would seem to imply a shift in responsibility, involving the competence of subjects other than municipal authorities. However, the planning system of Regione Toscana continues to be centred primarily on the municipal scale. Despite the PIT/PPR being both a strategic territorial plan (Piano di Indirizzo Territoriale, PIT) and landscape plan (Piano Paesaggistico Regionale, PPR), its direct planning proposal is weak, and it fails to affect decisions such as the location of new industrial and commercial areas in the region. The only actions directly promoted by the plan (known as landscape projects, Progetti di Paesaggio) that have been launched so far are funded feasibility studies, which almost exclusively concern the use of local landscape resources to promote tourism. The Plan's vision includes: (1) prefiguring a polycentric settlement criss-crossed by an infrastructure of navigable waterways and soft mobility embankments; (2) counteracting the phenomenon of abandonment and marginalisation of mountain towns; (3) advocating for the substantial funding of these territories, aiming to revive an economy based on local and artisanal production. These objectives are a long way from the implementation ability of planning tools on a local, municipal and provincial level; thus, the expression "guidelines for actions" seems, at least in this case, to define a sequence of policy statements rather than true regulatory action. The fourth theme-from which we can understand many associated guidelines from the Plan to the identification of settlement morphotypes - can be described as the protection of values regarding tradition settlement organisation in Toscana. In other words, safeguarding historical settlements in open territories (walled towns and castles, villas, farmhouses and estates, religious buildings, rural villages and roadways, networks of agricultural hydraulic systems). Finally, for the fifth theme, we can summarise PIT/PPR guidelines as indications for the restoration of traditional landscape. At the risk of simplifying the Plan's indications, the text presents an image of an epic commitment to restore traditional patterns that have been misshapen by modern transformations or at least to mitigate their effects, which include: the rebuilding recognisability of the territorial relationship between urban centres and agroforestry systems; rebuilding visual relationships compromised by the expansion of large conurbations through the delocalisation of production settlements and decongestion of waterways; and more generally, by mitigating the landscape impact of recent urbanisation. Finally, we must mention the specific and constant way that the PIT/PPR underlines the transformation and redevelopment of settlement edges in reference to the quality of facades built towards open territory, the seaside and embankments. The PIT/PPR's insistence on this issue is evidently linked to the specificity of the Tuscan settlement pattern, which the Plan describes as "polycentric and reticular". This technical term means that a large number of settlements have developed along communication routes favouring rural land parcelling. We must highlight that these elements generate critical aspects for subjects who will implement the "indications for actions" set out in the Plan. Beyond any other consideration, the commitment to restoring traditional patterns, or at least to mitigating the effects of recent urbanisation, despite the appeal of using "transfer of development rights", can only be imaginable with the extensive and extraordinary availability of public resources. Moreover, in a scenario such as the present, where resources are scarce, the funds needed for the morphological transformation of urban edges could be made available essentially as compensation for land development in these areas. However, there is no escaping that this indication is likely not reconcilable with the objective of eliminating the land consumption called for in both the PIT/PPR and territorial strategies that the Regione Toscana defined in the 2010s. Finally, there is a further difficulty in the PIT/PPR regarding the recognisability of its quality model for urban edges. Thus, it is appropriate to find more explicit indications in the Plan's wider discussion regarding urban quality. 


\subsubsection{Contemporary Urbanisation Morphotypes}

Contemporary urbanisation morphotypes identified by the PIT/PPR describe builtup settlement fabrics that date back to the post-Second World War period (cf. Figure 2). Classification takes place on two levels: a more general one that identifies four contexts differentiated by location and function (headings in the Table 1); these are then further divided by morphological criteria (columns in the Table 1).
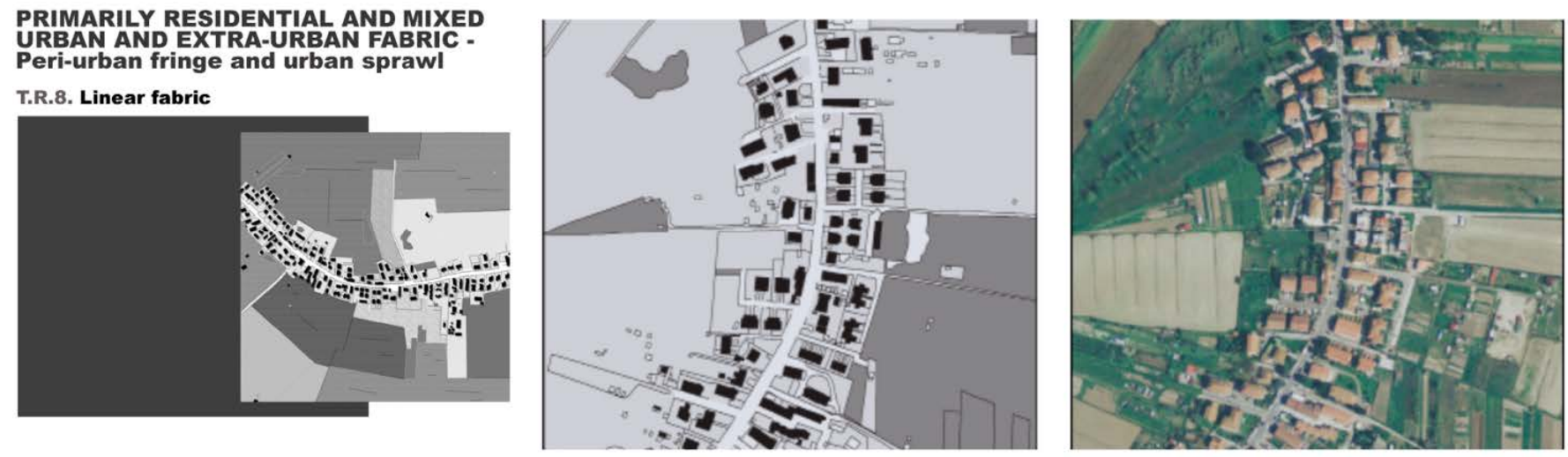

Figure 2. PIT/PPR, an example of contemporary urbanisation morphotypes, T.R.8 Linear fabric.

A summary of the urban quality model laid out by the Plan is present in the "specific objectives" associated with each morphotype, the pursuit of which is delegated to the plans and programmes that must conform to its indications. Unlike the cases of "settlement morphotypes", it appears that, in this circumstance, the pursuit of PIT/PPR objectives is primarily entrusted to municipal land-use planning tools.

These specific objectives identify existing spatial characteristics to be protected and not endangered, such as residual open spaces in dense blocks; the quality of contemporary buildings in planned cities; 'rural and diffuse' nature of inhabited countryside; functional unity between rural buildings, rural areas and agricultural land; building materials and masonry in rural villages; rural roadways and perifluvial belts. A second group of objectives involves criteria for organisation of public space and distribution of urban functions, such as: increase the provision and quality of public services; increase urban green areas by using unbuilt interior courtyards and free up space through building densification; build public service areas in marginal urban centres including occupation of enclosed spaces; reuse abandoned production buildings for public functions on a district scale; introduce functional elements in non-residential settlements that are excessively specialised. A third group concerns criteria for the landscape redevelopment of building stock, such as: encourage complex regeneration projects of existing fabrics through transfer of building rights, demolition and reconstruction of residential buildings for densification and the relocation of production buildings; restore permeability to artificialised land and improve energy efficiency of historical buildings by generating energy in production areas.

Finally, a fourth group of objectives concerns a prevalent theme named in the Plan as a key strategy to improve urban quality: the criteria for treatment of edges and reconstruction of the city-open territory interface. The PIT/PPR underlines the need to build "new city-open territory relationships" consisting of visual permeability, in the morphological definition of an external-facing urban front (in opposition to the current 'retro' condition). This morphological definition could use plant and building materials to create a 'green belt' of tree rows, orchards and peri-urban agricultural parks. The Plan recognises that this objective is difficult to achieve in the absence of public resources and should be pursued by adding the objectives of rural development programming to this theme. 
2.3.3. "Guidelines for Landscape Redevelopment of Urbanised Fabric in the Contemporary City"

Among its materials, the PIT/PPR contains a relevant document (Addendum 2) regarding the discussion of this theme. It is entitled "Guidelines for landscape redevelopment of urbanised fabric in the contemporary city" and linked to the notion of "contemporary urbanisation morphotypes" identified the PIT/PPR. The guidelines, which were subsequently drafted to the definition of the above-mentioned morphotypes, were written by one of the authors and designed to be used in the process of drafting Piani Operativi (PO, Operational Plans).

The guidelines, also entitled "illustrated guide for redevelopment of urbanised fabric", are three-dimensional images on a larger scale than all other PIT/PPR documents (about 1:1000) and propose the following objectives: (i) represent the spatial characteristics of urbanised fabrics identified in the regional abacus, generalising and abstracting with respect to the multiple contexts present in the regional territory (cf. Figure 3); (ii) highlight planning choices - through the planovolumetric restitution of 'pejorative' consequences of design behaviour that are inconsistent with PIT/PPR quality objectives-that could exasperate landscape problems related to each invariant, "with particular reference to the quality of nearby non-urbanised space" (cf. Figure 4); (iii) illustrate spatial configuration theories that are consistent with the abovementioned quality objectives (cf. Figure 5).

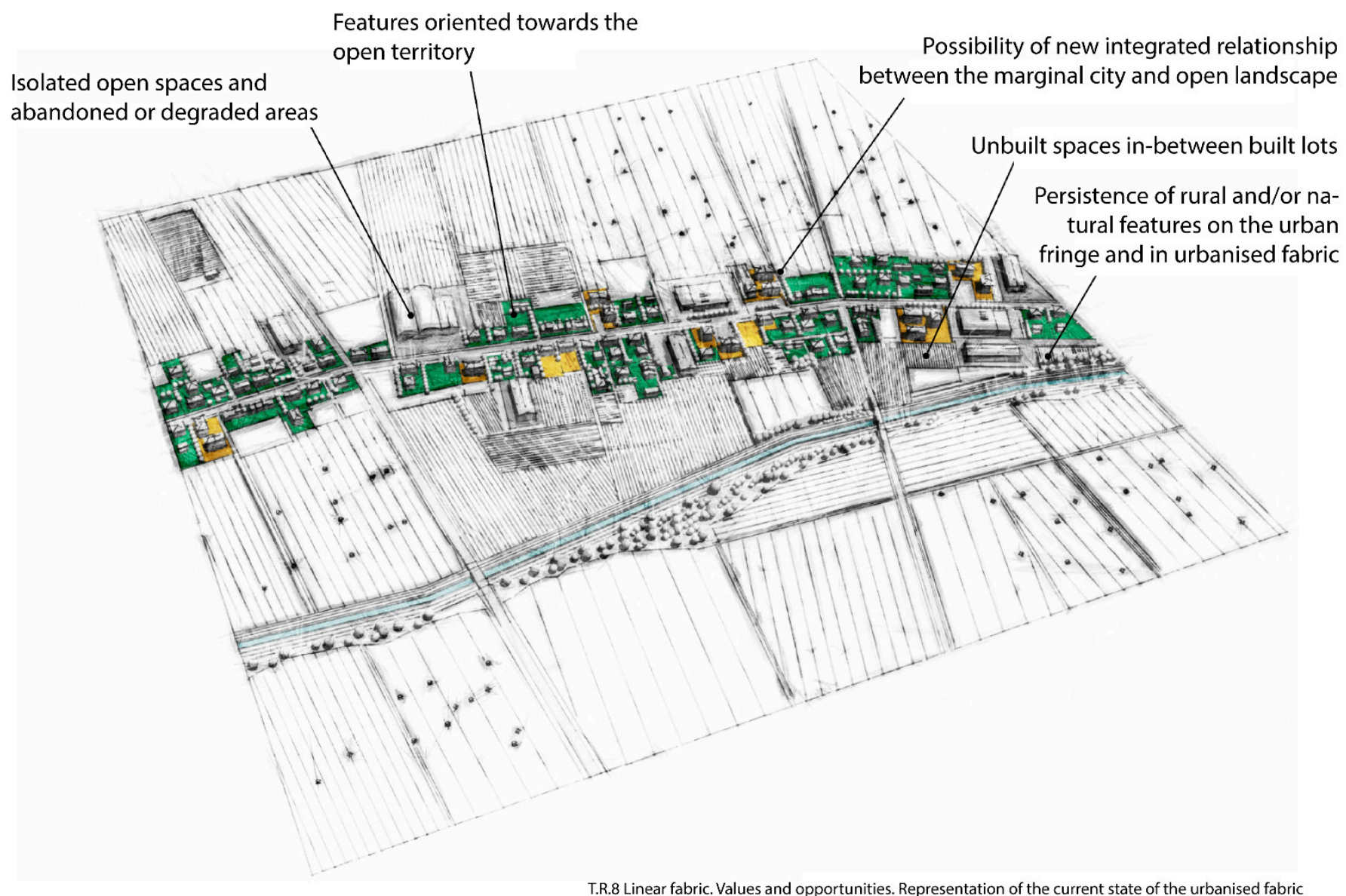

Figure 3. "Guidelines for landscape redevelopment of urbanised fabric in the contemporary city", excerpt from section T.R.8 Linear fabric, state of fact. 


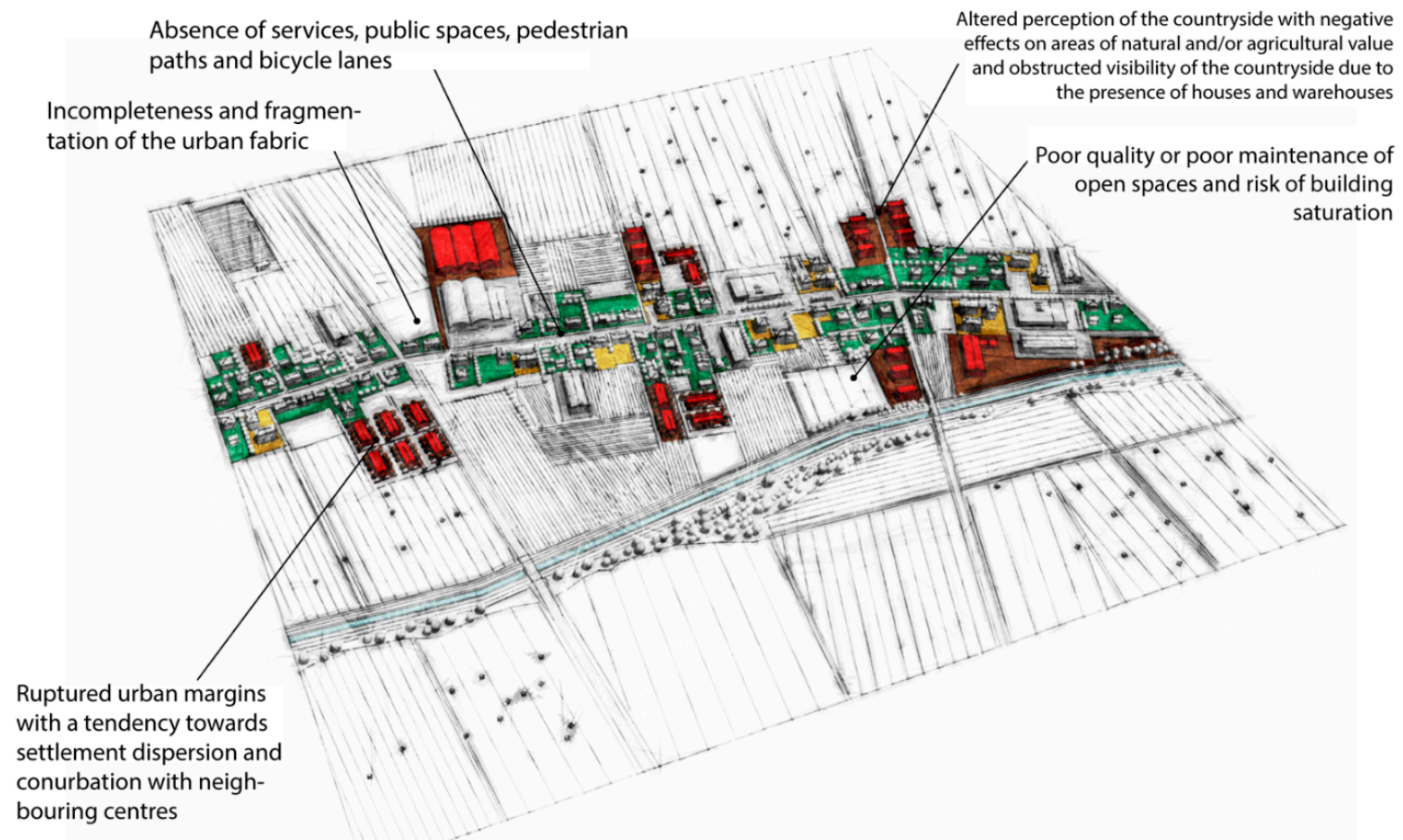

T.R.8 Linear fabric. General view: pejorative hypothesis with respect to the quality objectives of the PIT/PPR

Figure 4. PIT/PPR, Guidelines for landscape redevelopment of urbanised fabric in the contemporary city, excerpt from section T.R.8 Linear fabric, pejorative hypothesis.

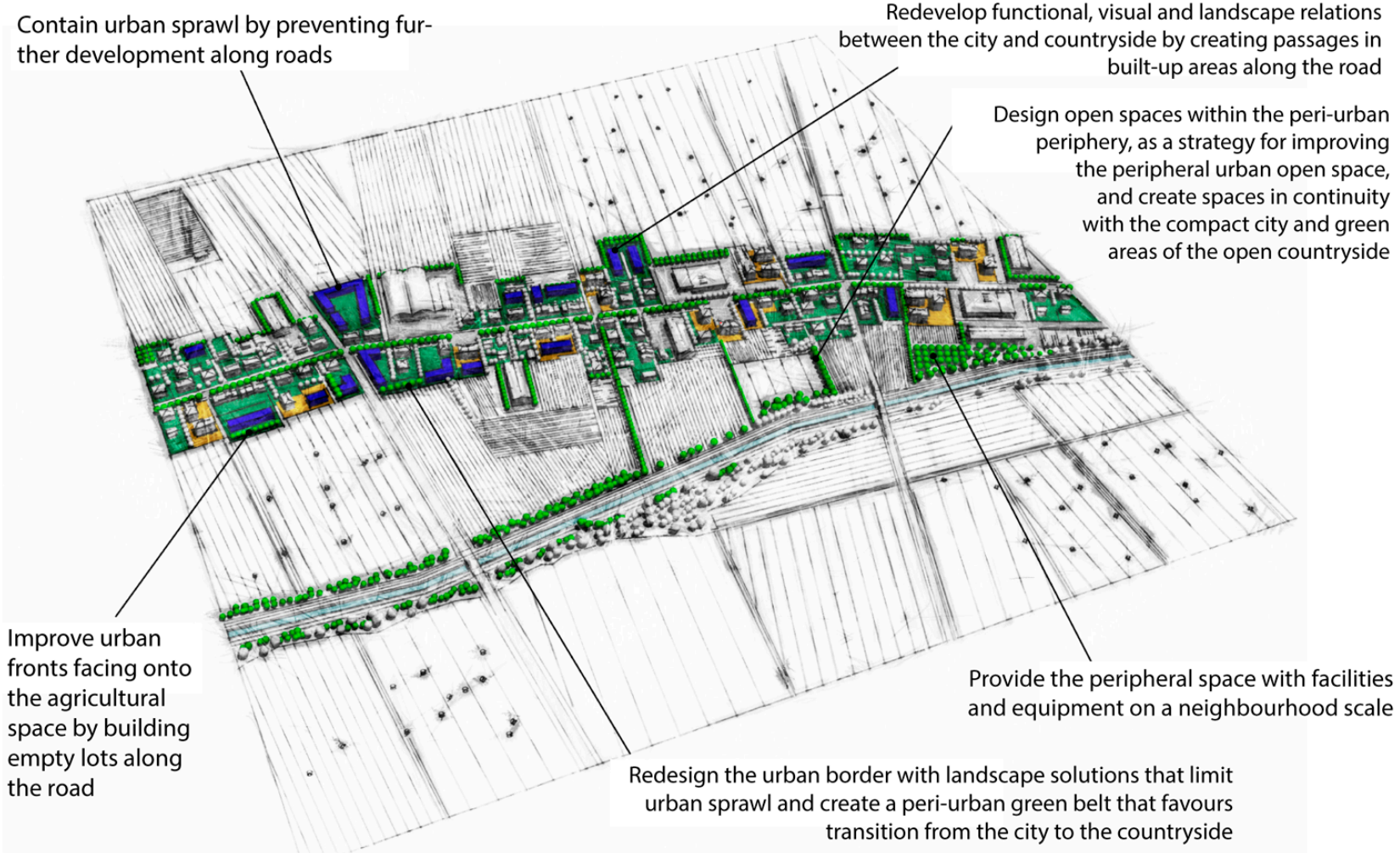

T.R.8 Linear fabric. General view: hypothesis consistent with the quality objectives of the PIT/PPR

Figure 5. PIT/PPR, Guidelines for landscape redevelopment of urbanised fabric in the contemporary city, excerpt from section T.R.8 Linear fabric, meliorative hypothesis. 
We must clarify that of all urban fabrics addressed in the guidelines, the following, although present in the abacus of regional morphotypes, were not considered: T.R.1 (Fabric with closed or semi-closed blocks); T.R.2 (Fabric with open blocks and isolated residential lots) T.R.3 (Fabric with open blocks and primarily residential lots), as these fabrics generally do not have borders with open or natural spaces due to their conformation. Thus, the choice to not address them in the guidelines confirms that this document was designed specifically for urban edges.

The guidelines delineate behaviour advocated by the PIT/PPR with respect to recurrent situations and, in this sense, allow for 'guidance' through consultation with various figures involved in the drafting process of the PO (e.g., PO designers, private operators proposing transformations, writers of implementation plans, etc.) (cf. Figure 6).

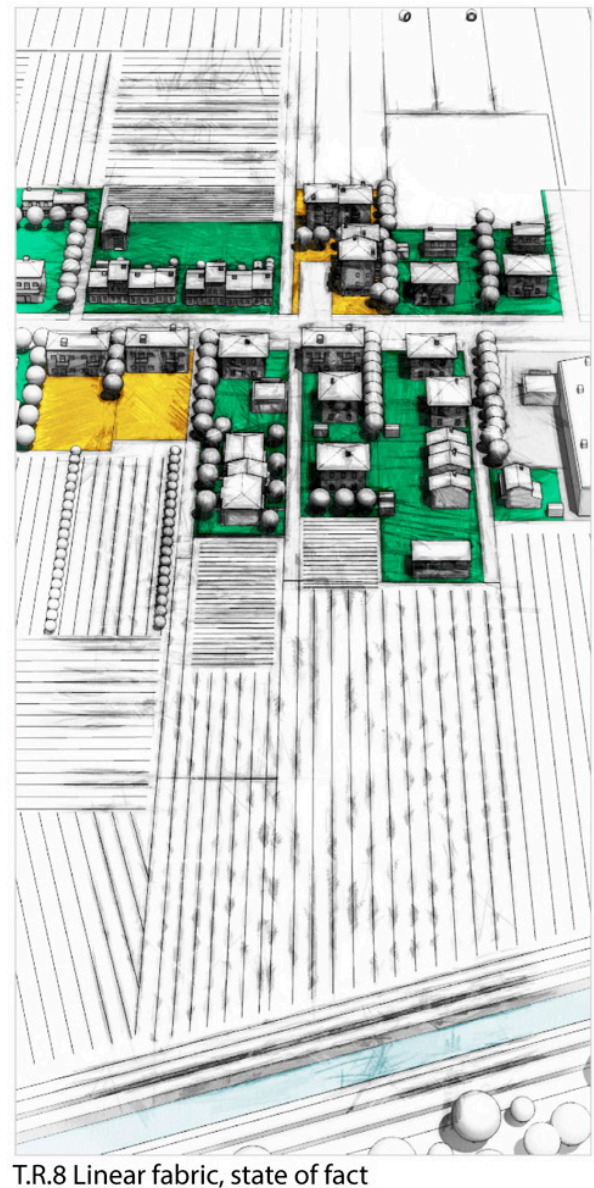

T.R.8 Linear fabric, state of fact

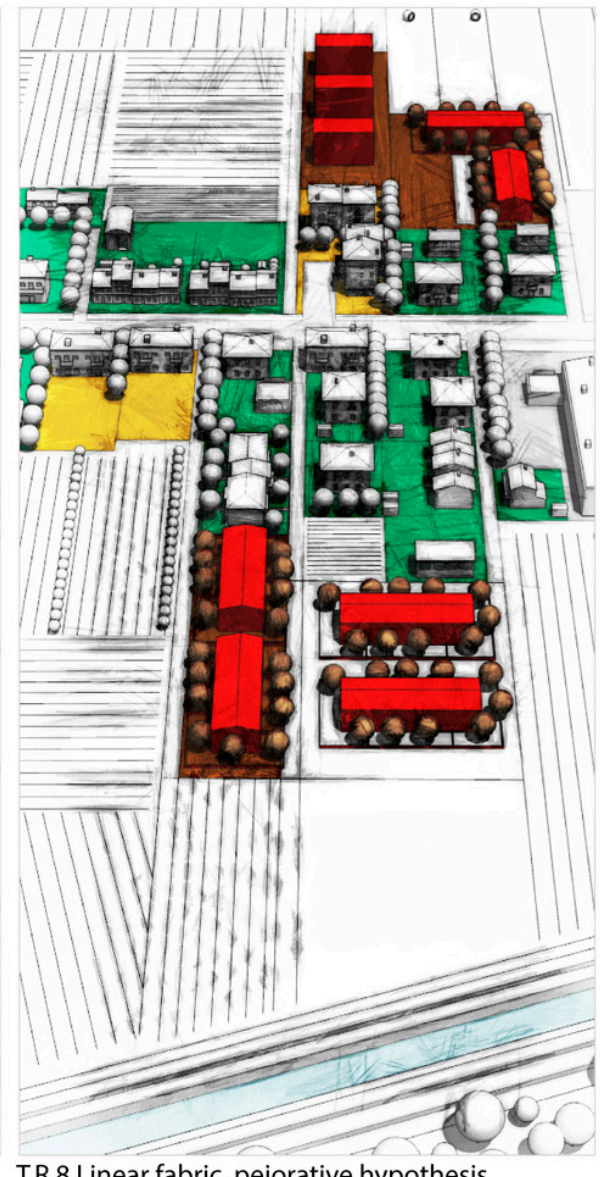

T.R.8 Linear fabric, pejorative hypothesis

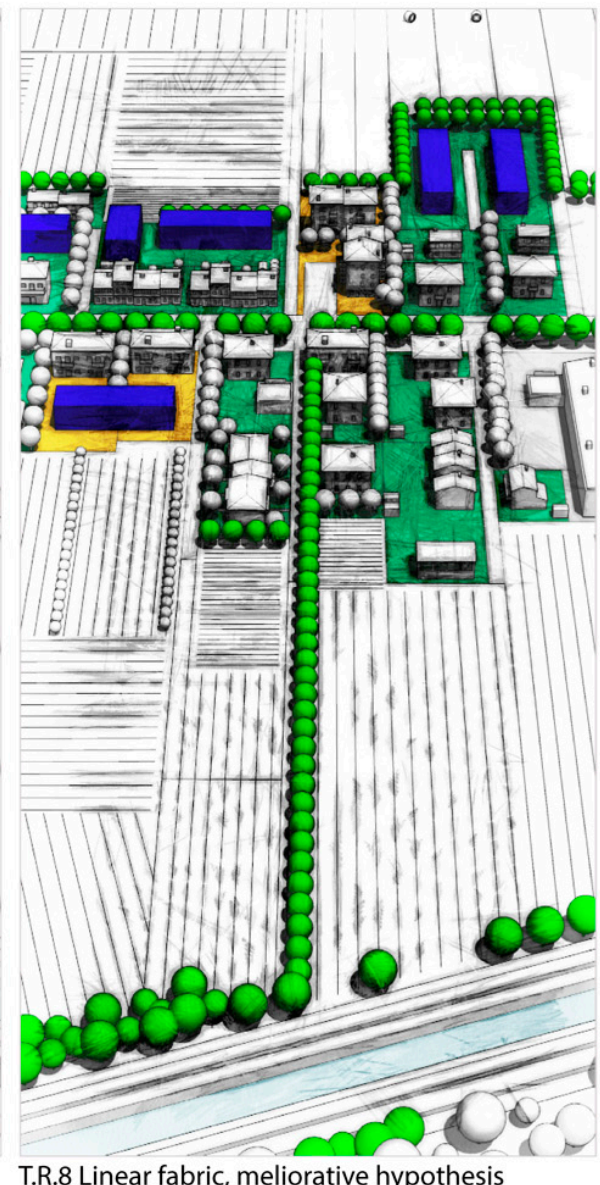

T.R.8 Linear fabric, meliorative hypothesis

Figure 6. PIT/PPR, guidelines for landscape redevelopment of urbanised fabric in the contemporary city: excerpt from section T.R.8 Linear fabric, state of fact and alternative hypotheses.

\section{Methods: Assessment of the Regulatory Effectiveness of the Pit/Ppr of Regione Toscana with Respect to Urban Quality}

\subsection{Examination of Municipal Plans}

As previously stated, topics that concern settlement quality constitute the thematic field of the structural invariant known as "polycentric and reticular nature of urban and infrastructural settlement systems". With respect to this thematic field, the PIT/PPR discipline identifies general objectives (Discipline of the Plan, art. 9) and proposes directives (Discipline of the Plan, art. 12) that define provisions to be adopted "in the development and implementation of urban and territorial planning tools, as well as plans and programmes that have territorial effects". In particular (Discipline of the Plan, art. 12, par. 3), according to these directives, in their urban planning tools, municipalities pursue "specific objectives 
related to each contemporary urbanisation morphotype, ( . . . ) in order to classify urban fabrics and the design of their edges".

The PIT/PPR was definitively approved at the end of March 2015. Following this approval, the revision phase of Tuscan municipal planning tools began. That revision was needed to both adopt landscape plan objectives and comply with provisions of LR 65/2014 on territory government that were approved in the previous year. This law obligates municipal authorities to begin formulating a new PS, or at least a variation in the existing PS, within five years of its approval.

A proper reflection on the regulatory effectiveness of the PIT/PPR's legal provisions regarding settlement transformations and quality of urban environments should consider all supply chain elements, including the level of land-use planning.

Regione Toscana entrusts the monitoring of the formulation of urban and territorial planning tools to the Equal Planning Observatory, which carries out this activity along with a verification of indicators on the state of settlements, the most relevant of which is land consumption. As of 27 September 2021, the Observatory has deemed that seven municipal authorities have approved an ordinary PO, in other words based on a PS written in compliance with LR 65/2014 (https:/ / www.regione.toscana.it/-/stato-della-pianificazione). In the Table 2, we present the municipalities named by the Observatory along with the municipality of Lastra a Signa, which concluded its approval process in November 2021. Territories of the administrations involved are presented through: (i) number of inhabitants; (ii) overall extension of artificialized land present; (iii) assessment (produced by the Ministry of the Economy and refined by the Institute for Research and Economic Planning of Toscana) of accessibility and services present and classification as Hub, Belt, Intermediate, Remote or Ultra-remote.

Table 2. The municipalities that approved an ordinary PO in compliance with LR 65/2014, Nov. 2021.

\begin{tabular}{|c|c|c|c|c|c|}
\hline & $\begin{array}{l}\text { Month/Year of } \\
\text { PS Approval }\end{array}$ & $\begin{array}{c}\text { Month/Year of } \\
\text { PO Approval }\end{array}$ & $\begin{array}{c}\text { (i) Number of } \\
\text { InHabitants } \\
\text { (ISTAT 01/01/2021) }\end{array}$ & $\begin{array}{c}\text { (ii) Land } \\
\text { Consumption (ha) } \\
\text { (ISPRA 2020) }\end{array}$ & (iii) Classification \\
\hline $\begin{array}{l}\text { Greve in Chianti } \\
\text { (Firenze) }\end{array}$ & $03 / 2019$ & 03/2019 & 13,470 & 668 & Intermediate \\
\hline $\begin{array}{l}\text { Lastra a Signa } \\
\text { (Firenze) }\end{array}$ & $12 / 2018$ & $09 / 2021$ & 19,441 & 509 & Belt \\
\hline $\begin{array}{l}\text { Montemurlo } \\
\text { (Prato) }\end{array}$ & $12 / 2018$ & $04 / 2019$ & 18,801 & 619 & Belt \\
\hline $\begin{array}{l}\text { Peccioli } \\
\text { (Pisa) }\end{array}$ & $\begin{array}{c}12 / 2015 \text { (general } \\
\text { variant) }\end{array}$ & $07 / 2018$ & 46,49 & 388 & Intermediate \\
\hline $\begin{array}{l}\text { Quarrata } \\
\text { (Pistoia) }\end{array}$ & $03 / 2017$ & $07 / 2020$ & 26,648 & 745 & Intermediate \\
\hline $\begin{array}{l}\text { Scandicci } \\
\text { (Firenze) }\end{array}$ & $\begin{array}{c}\text { 04/2019 (general } \\
\text { variant) }\end{array}$ & $04 / 2019$ & 50,592 & 926 & Belt \\
\hline $\begin{array}{l}\text { Vaglia } \\
\text { (Firenze) }\end{array}$ & $02 / 2020$ & $03 / 2020$ & 5218 & 235 & Intermediate \\
\hline $\begin{array}{l}\text { Vicchio } \\
\text { (Firenze) }\end{array}$ & $04 / 2019$ & $10 / 2019$ & 7794 & 386 & Remote \\
\hline
\end{tabular}

Thus, the number of cases is quite limited. All of these municipalities are located in central-northern Toscana, which is the most urbanised area of the region (cf. Figure 7). They are small- to medium-sized municipal administrations in terms of population and settlement size. The three larger towns (Scandicci, Montemurlo and Lastra a Signa) are part of the Florentine metropolitan area, while the four smaller towns (Quarrata, Peccioli, Vaglia and Greve in Chianti) are less accessible and have less services. The eighth town, Vicchio, in the Mugello Valley, is the most remote of the sample cases. 


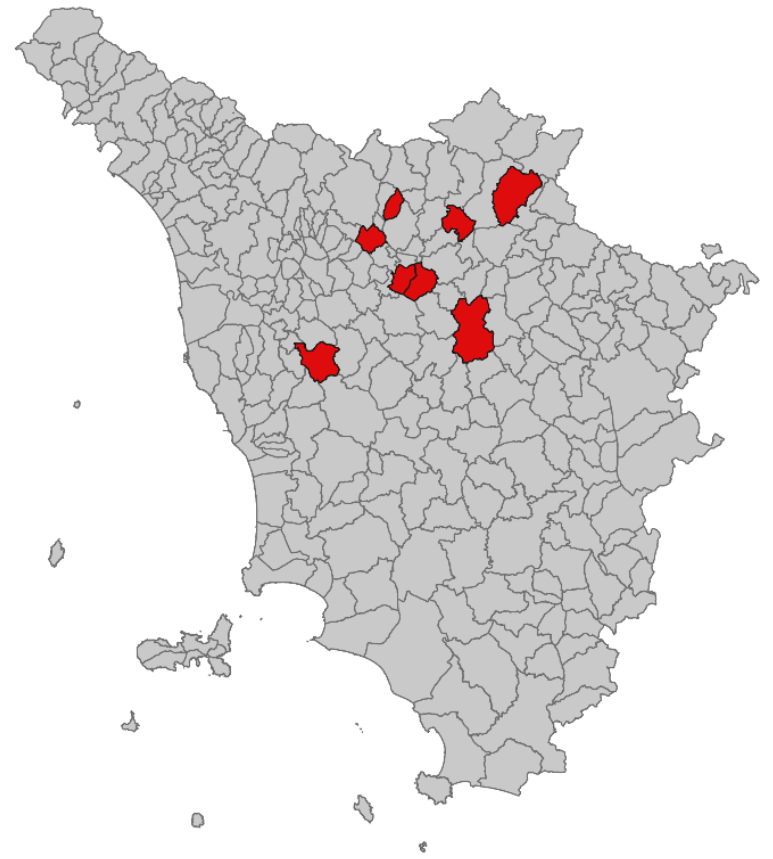

Figure 7. Tuscany: the location of the municipalities listed in Table 2.

All of the constituent documents of the PS and PO of the sample cases were collected and examined with the objective of verifying the PIT/PPR's ability to configure, or renew, analytical attitudes and design choices concerning settlement quality. These local plans were examined for the following purposes: (i) verify the adoption of the PIT/PPR's "indications for actions" for settlement quality; (ii) verify how local plans technically interpreted PIT/PPR directives regarding the delineation of contemporary urbanisation morphotypes, and if necessary, in compliance with LR 65/2014 with respect to the perimeterisation of urbanised territory; (iii) verify if the taxonomy of settlements and urban fabrics proposed by the PIT/PPR as directives for land-use plans played a role in defining plan actions and management choices regarding existing building stock; (iv) verify if and in what form specific objectives related to each contemporary urbanisation morphotype defined by the PIT/PPR are found in the actions defined by local land-use planning that aims to transforms urban fabrics and redevelop the design of their edges.

\subsection{Interviews with Designers}

Following our documentational analysis of the municipal plans listed in Table 2, we believed it useful to carry out a more in-depth study on the topics of interest to this research through structured interviews with several plan designers.

Analysing the composition of working groups that drafted the municipal plans in Table 2, we decided to interview a significant sample of the designers of the plans listed in the table, who are either external professional designers selected by municipal authorities or internal designers from municipal offices. In our given time frame, we were able to interview four designers who were responsible for five of the eight plans we reviewed.

More precisely (referring to Table 4), designers 1 and 2 are external consultants and authored two plans and one plan, respectively. Designers 3 and 4 are internal to their respective administrations and wrote one plan each. Being a designer of urban planning tools requires specific technical/scientific preparation (interviewees were all architects who specialised in urban planning) and involves responsibilities that include: coordinating working groups that draft plans; managing relations with administrations and superordinate authorities; facilitating meetings and conferences, including those with citizens; supervising the entire drafting process. Thus, these professionals have an overall vision of the complete drafting process and a thorough knowledge of sector regulations and 
procedures, various territorial government tools and working dynamics of the territories involved. Individual interviews took place remotely via digital platforms, were entirely recorded and lasted for about $45 \mathrm{~min}$ each. They were based on a list of questions drafted by the authors of this paper with the following goals: (1) further highlighting several aspects that emerged from the documentational analysis of the plans and (2) bringing to light other aspects that may have not yet emerged from this analysis. Thus, the interviews began with a more general discussion, and then moved on to a more detailed assessment of the PIT/PPR's effectiveness in elevating urban quality as called for in municipal plans.

In the first part of the interview, in the framework of urban quality, designers were asked to assess the: PIT/PPR in its entirety (question A); PIT/PPR in conjunction with LR 65/2014 (question B); and the effectiveness of the different procedures (question C).

In the second part, they were asked to assess the effectiveness of the PIT/PPR in orienting urban quality in Tuscan towns (question D); morphotype system (question E); guidelines (question F); PIT/PPR's effectiveness in increasing urban edge quality (question G).

Interview results are discussed below.

\section{Results}

\subsection{Results of the Municipal Plan Examination}

4.1.1. Verification of the Presence of Explicit References to PS Regulations as "Indications for Actions" Regarding Settlement Morphotypes in Regulations of Examined PS

As previously stated, the "guidelines for actions" proposed by the PIT/PPR regarding the identification of "settlement morphotypes" in the regional territory appears to not have any real possibility of immediately producing recognisable effects on urban and territorial planning regulations. Both the general nature of the objectives and the absence of an adequate level of territorial governance render these guidelines more akin to policy statements rather than actual government acts, even if we must admit that this judgment could be revised as a result of the progressive expansion of intermunicipal structural planning initiatives. In fact, in the majority of the examined PS (Greve in Chianti, Peccioli, Scandicci, Vaglia, Vicchio), there are no references to either settlement morphotypes or "guidelines for actions" for their recognition. In the Lastra a Signa PS, the contextualisation of the municipal territory as a "polycentric urban settlement morphotype of the great flood plains" is cited in an addendum to the cognitive framework but has no effect in the plan regulation. For Quarrata and Montemurlo, the paper is limited to two aspects: (1) adopting PIT/PPR descriptive materials and regulatory requests, which are transcribed to the letter in the case of Quarrata and described with better adherence to the specific context in the case of Montemurlo; (2) confirming the PO's obligation to clearly state all planned actions. However, even in these cases, the regulatory structure of land-use planning tools does not discuss any action it takes as a result of conformity to PIT/PPR indications (cf. Table 3, Column i).

Table 3. Summary of the results of the examination of the municipal plans.

\begin{tabular}{|c|c|c|c|c|}
\hline $\begin{array}{l}\text { Approved PO That } \\
\text { Conform to the } \\
\text { PIT/PPR }\end{array}$ & $\begin{array}{l}\text { (i) Explicit References to } \\
\text { PS Regulations as } \\
\text { "Indications for Actions" } \\
\text { Regarding Settlement } \\
\text { Morphotypes }\end{array}$ & $\begin{array}{c}\text { (ii) Mapping of } \\
\text { Contemporary Urbanisation } \\
\text { Morphotypes }\end{array}$ & $\begin{array}{c}\text { (iii) References to } \\
\text { Contemporary } \\
\text { Urbanisation } \\
\text { Morphotypes for PO } \\
\text { Discipline on Existing } \\
\text { Building Stock }\end{array}$ & $\begin{array}{l}\text { (iv) References to } \\
\text { Contemporary } \\
\text { Urbanisation } \\
\text { Morphotypes for PO } \\
\text { Discipline on } \\
\text { Transformations }\end{array}$ \\
\hline Greve in Chianti (FI) & $\mathrm{NO}$ & $\begin{array}{c}\text { Present in the PS } \\
\text { (Table QC8 "Contemporary } \\
\text { urbanisations morphotypes") }\end{array}$ & $\mathrm{NO}$ & $\begin{array}{c}\text { YES } \\
\begin{array}{c}\text { References in regulation } \\
\text { data sheets }\end{array}\end{array}$ \\
\hline Lastra a Signa (FI) & $\mathrm{NO}$ & $\begin{array}{c}\text { Present in the PS } \\
\text { "Invariants from the PIT/PPR } \\
\text { and PTC Urbanised territory"; } \\
\text { Table QC } 2 \text { III-IV "Invariants } \\
\text { from the PIT/PPR") }\end{array}$ & $\mathrm{NO}$ & $\begin{array}{c}\text { YES } \\
\text { References in regulation } \\
\text { data sheets }\end{array}$ \\
\hline
\end{tabular}


Table 3. Cont.

\begin{tabular}{|c|c|c|c|c|}
\hline $\begin{array}{l}\text { Approved PO That } \\
\text { Conform to the } \\
\text { PIT/PPR }\end{array}$ & $\begin{array}{l}\text { (i) Explicit References to } \\
\text { PS Regulations as } \\
\text { "Indications for Actions" } \\
\text { Regarding Settlement } \\
\text { Morphotypes }\end{array}$ & $\begin{array}{c}\text { (ii) Mapping of } \\
\text { Contemporary Urbanisation } \\
\text { Morphotypes }\end{array}$ & $\begin{array}{c}\text { (iii) References to } \\
\text { Contemporary } \\
\text { Urbanisation } \\
\text { Morphotypes for PO } \\
\text { Discipline on Existing } \\
\text { Building Stock }\end{array}$ & $\begin{array}{l}\text { (iv) References to } \\
\text { Contemporary } \\
\text { Urbanisation } \\
\text { Morphotypes for PO } \\
\text { Discipline on } \\
\text { Transformations }\end{array}$ \\
\hline Montemurlo (PO) & YES & $\begin{array}{c}\text { Present in the PS } \\
\text { (Table QC06 "Urban and } \\
\text { extra-urban fabrics") }\end{array}$ & $\mathrm{NO}$ & $\mathrm{NO}$ \\
\hline Peccioli (PI) & $\mathrm{NO}$ & $\begin{array}{c}\text { NO } \\
\text { References to objectives cited } \\
\text { in the "Supporting report to } \\
\text { PO Conformation" }\end{array}$ & $\mathrm{NO}$ & $\mathrm{NO}$ \\
\hline Quarrata (PT) & YES & $\begin{array}{c}\text { Present in the PS } \\
\text { (Table QC09 "Map of urban } \\
\text { and extra-urban fabrics") }\end{array}$ & $\mathrm{NO}$ & $\mathrm{NO}$ \\
\hline Scandicci (FI) & $\mathrm{NO}$ & $\begin{array}{c}\text { NO } \\
\text { Cited and described in the PS } \\
\text { (Variant of adjustment to the } \\
\text { PIT/PPR, art. 54, par. 4); refers } \\
\text { to a perimeterisation of } \\
\text { urbanised territory in Table } 3 \\
\text { "Structural invariants". } \\
\text { Objectives are verbatim to } \\
\text { art. 55, par. 3 }\end{array}$ & $\mathrm{NO}$ & $\begin{array}{c}\text { YES } \\
\text { Reference to "Guidelines } \\
\text { for landscape } \\
\text { redevelopment of } \\
\text { urbanised fabrics in the } \\
\text { contemporary city" }\end{array}$ \\
\hline Vaglia (FI) & $\mathrm{NO}$ & $\begin{array}{c}\text { Present in the PS } \\
\text { (Table STA03 "Territorial and } \\
\text { settlement structure") }\end{array}$ & $\begin{array}{c}\text { YES } \\
\text { (With slight } \\
\text { nominal changes) }\end{array}$ & $\mathrm{NO}$ \\
\hline Vicchio (FI) & $\mathrm{NO}$ & $\begin{array}{l}\text { Present in the PS (Table P3a } \\
\text { "Third invariant: morphotypes } \\
\text { of the contemporary city and } \\
\text { urbanised territory" }\end{array}$ & $\mathrm{NO}$ & $\mathrm{NO}$ \\
\hline
\end{tabular}

4.1.2. Verification of the Presence of Mapping of Contemporary Urbanisation Morphotypes in Examined Planning Tools

A different role is played by the "specific objectives related to contemporary urbanisation morphotypes", which are referenced directly in the PIT/PPR Discipline as "the cognitive tool and technical-operational reference for the processing of urban and territorial planning with reference to the development of urban fabrics and the design of their edges" (art. 4, cl. 3); and subsequently cited in a directive that calls for the following provision "in the formulation of urban planning tools, Municipalities pursue specific objectives related to each contemporary urbanisation morphotype, as described by the PIT/PPR for the classification of urban fabrics and the design of their edges" (art. 12, par. 3). Thus to summarise, when formulating their territorial planning tools (the PS) and their urban planning tools (the PO), municipalities must: (i) when drafting their PS, use the taxonomy of contemporary urbanisation morphotypes present in the PIT/PPR as a fundamental cognitive tool and technical-operational reference; and (ii) when drafting their PO, adopt specific objectives assigned by the PIT/PPR to each morphotype in order to classify urban fabrics and the design of their edges. Regarding land-use planning, the PIT/PPR introduces an obligation to use an unprecedented type of zoning as opposed to the traditional Italian approach, which is based on national laws passed in 1967/1968 that are still in effect today. The approach to urban land-use planning defined at that time set limits for both building density and the ratio between private spaces (for residential/productive use) and public (or collective) spaces. These quantitative limits were assigned according to "homogeneous territorial zones", the recognition and delineation of which had to be contained in planning tools. Over time, in the drafting practices of urban planning instruments, traditional zoning has also been based on qualitative parameters and objectives, most of which aim to manage building transformations in continuity with existing typological characteristics. The 
PIT/PPR is part of this experimentation, as it identifies criteria for defining "homogeneous territorial zones" and provides a specific set of quality objectives. However, as we will see, its relation to the traditional approach is not without ambiguity.

The examined case studies present different solutions with respect to this theme (cf. Table 3, Column ii). For the municipalities of Scandicci and Peccioli, the examination of published materials related to the general variant of adjustment to the PIT/PPR did not reveal an effective mapping of morphotypes. In all the other cases, structural planning tools contain the mapping in dedicated tables rather than addenda. However, the methods used to create perimeters are rather differentiated. The Montemurlo PS (approved in 12/2018) does not precisely identify internal parts of the urbanised territory but rather uses vaguely spatialised labelling that indicates the presence of morphotypological classes on a scale of 1:10,000. The task of being more precise is entrusted to the PO, "the subsequent acts of territorial government, and firstly the $\mathrm{PO}$, describe in more detail the perimeters of urban and extra-urban fabrics and implement the specific objectives of contemporary urbanisation morphotypes by addressing them in the discipline of land use" (Montemurlo PS, Technical implementation standards, p. 30). However, the Montemurlo PO (approved in 4/2019) is less committed to defining a more accurate perimeterisation: "in identifying and regulating urban and extra-urban fabrics, the PO clarified the location of morphotypes reducing it to zonings of the previous PO and adopting the Plan's regulations and provisions in specific objectives and operational guidelines for various morphotypes" (Montemurlo PO, Report on conformity with the PS, PTC and PIT/PPR, p. 22). We can do nothing else but report how, in this passage, the notion of contemporary urbanisation morphotype loses its nature of "fundamental cognitive tool and technical-operational reference", with consequences that will be discussed along with the effectiveness of the role of analytical categories proposed by the PIT/PPR to inform the actions of urban quality improvement. In the other examined cases, identification of morphotypes is conducted by categorising land area based on PIT/PPR classification (as in the case of Greve in Chianti, Quarrata, Vaglia, Vicchio), in other words, excluding the road system, public spaces and unbuilt areas within the urbanised territory from the perimeterisation. The identified areas tend to be very small, less than one block in size. The only exception to this condition is the case of Lastra a Signa (approved in 12/2018), in which the PS categorises all of the space within the urbanised territory based on PIT/PPR classification.

4.1.3. Verification of the Presence of References to Contemporary Urbanisation Morphotypes for the Discipline of Existing Building Stock in Examined PO

According to LR 65/2014, the PO is organised into two sections: one focuses on the management of existing building stocks and the other on rules for urban transformations. Thus, it is legitimate to ask which of the two parts must adopt urban quality objectives of the PIT/PPR "by addressing them in the discipline of land use". This question should not appear naive, considering that the observation of PO conformant with the Plan reveals divergent interpretations (cf. Table 3, Column iii). The Vaglia PO (approved in 3/2020) is the only plan that uses morphotype zoning for the management of existing building stock. Land area within the urbanised territory is divided according to classification of morphotypes, which includes the identification of very small portions that are no bigger than one block. The requirements associated with this zoning (Vaglia PO, Technical implementation standards, Chapter 2 "Discipline of morphotypes in urbanised territory") govern land use for both the definition of admissible functions and categories of building work, at least for buildings that are not otherwise classified. We must admit that PIT/PPR taxonomy adopted in this way is simply another version of zoning with which building transformations are governed in current practices. The association of PIT/PPR quality objectives with the zoning of such a small spatial grain produces involuntarily bizarre effects. Let us consider the example in Figure 8. 

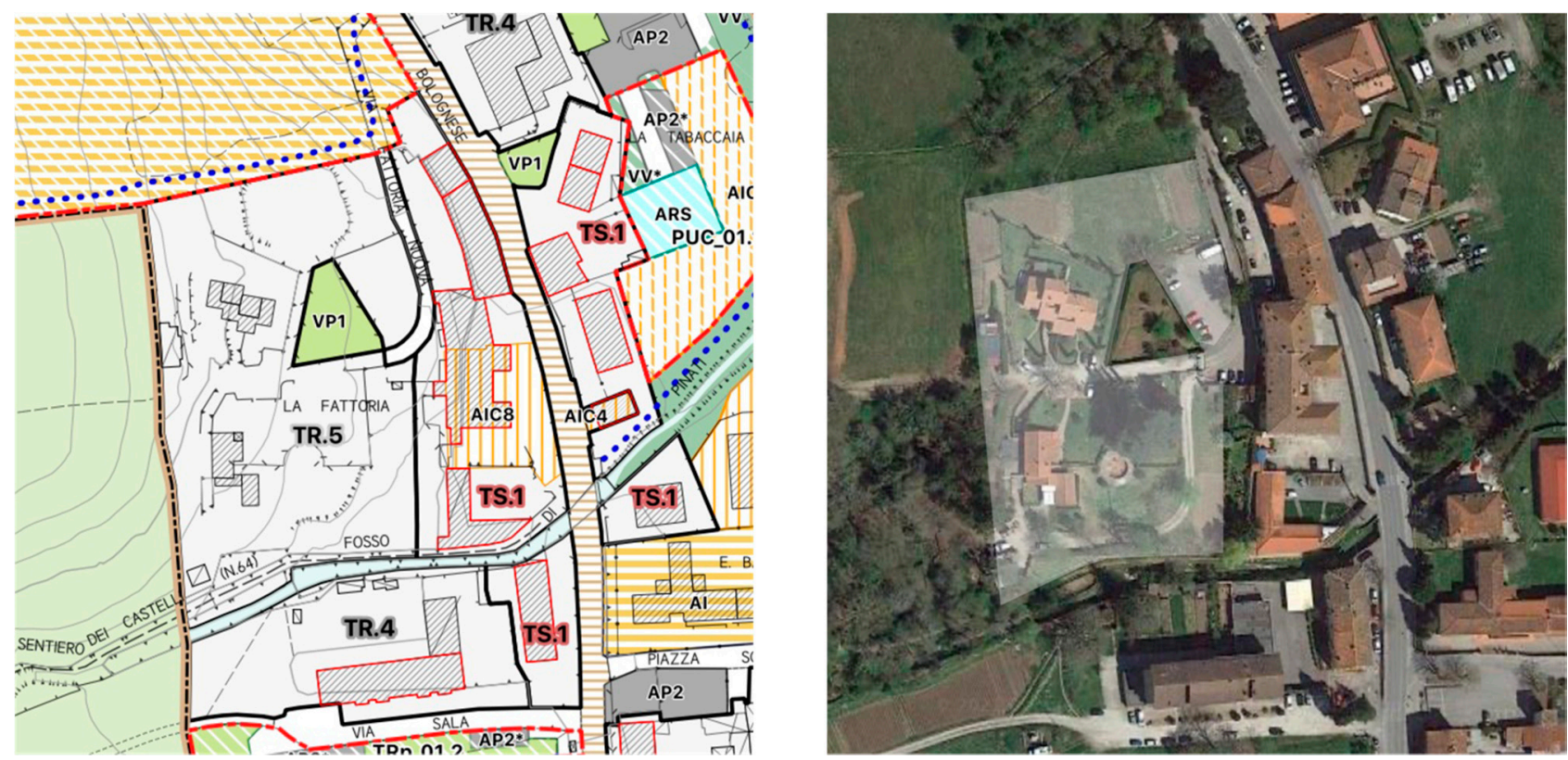

Figure 8. Mapping of contemporary urbanisation morphotypes in Vaglia PO (excerpt); the acronym T.R.5 identifies a "punctiform contemporary urbanisation morphotype". In this case, the PO implements the PIT/PPR by assigning landscape quality objectives designed for a large-scale intervention in an area occupied by only two isolated houses.

On a narrow valley floor wedged in the hills that separate Florence from Mugello near the town of Vaglia, there is an area that developed along a state road made up of two isolated houses, which has been perimetered and classified as "T.R.5 punctiform contemporary urbanisation morphotype". For this reason, regulations related to the discipline of land (Vaglia PO, art. 11) obligate, with a wording that in not always clear, the use of PIT/PPR objectives for this type of fabric as (1) "promoting an urban landscape project that can generate a porous urban space starting from a low-density fabric giving the settlement a clear urban matrix while valorising the continuous shift between urban-rural relations" and (2) "building 'urban boulevards' in the district, transforming main roads into 'functional thoroughfares' lined with public or residential services".

This effect, which is paradoxical due to the evident contrast between the scale of the objectives and that of the area of application, is avoided by all the other sample cases that follow the aforementioned expedient, explained during the conformation conference of the Montemurlo PO. All of the other cases confirmed traditional types of zoning aimed at managing building transformations to be implemented through direct interventions. Therefore, at least in the form of the PO, they have excluded references to PIT/PPR regulations in the discipline of existing building stock. In some situations (Montemurlo, Peccioli and Quarrata), the PO contains no reference to PIT/PPR taxonomy or objectives; for this reason, it is extremely difficult to verify conformity with its directives.

4.1.4. Verification of the Presence of References to Contemporary Urbanisation Morphotypes in the Discipline of Transformations in Examined PO

As can be seen from the summary in Table 3, in the majority of examined cases, PO regulations that contain requirements for transformation areas do not contain direct references to specific PIT/PPR objectives regarding contemporary urbanisation morphotypes (cf. Table 3, Column iv). Only in a few of the examined situations (Greve in Chianti, Lastra a Signa and Scandicci) is a reference to PIT/PPR objectives explicitly present. In Scandicci, the "regulation data sheets" addended to the technical implementation standards, referring to specific PIT/PPR objectives only for interventions "pertinent to the size and nature of the intervention and to the characteristics of the reference context". The selected cases 
suggest that the criterion of relevance is in the proximity of the intervention to the urban edge. It is likely useful to emphasise that the Scandicci PO does not refer directly to the PIT/PPR but rather to some marginal content in the Plan, such as "Guidelines for landscape redevelopment of urbanised fabric in the contemporary city" (Addendum 2).

The PO regulations of Lastra a Signa (approved in 11/2021), the only case of all those examined, associate PIT/PPR objectives for the "reference morphotype" with each transformation area. The Lastra PO adopts these objectives with an apparently sincere conviction, as the references are not written verbatim, as seen in many other situations, but modified and integrated to render them more adherent to specific local conditions. The objectives appear to be well-proportioned with respect to the spatial scale of the intervention. Finally, it is useful to point out that recognition of this outstanding condition in the examined framework must be associated with the technique used for zoning delineation (i.e., the Lastra PO has designed morphotypes better than all of the other examined samples, (cf. Figure 9), extended to the involvement of public space and able to properly indicate "fabrics" rather than "blocks".
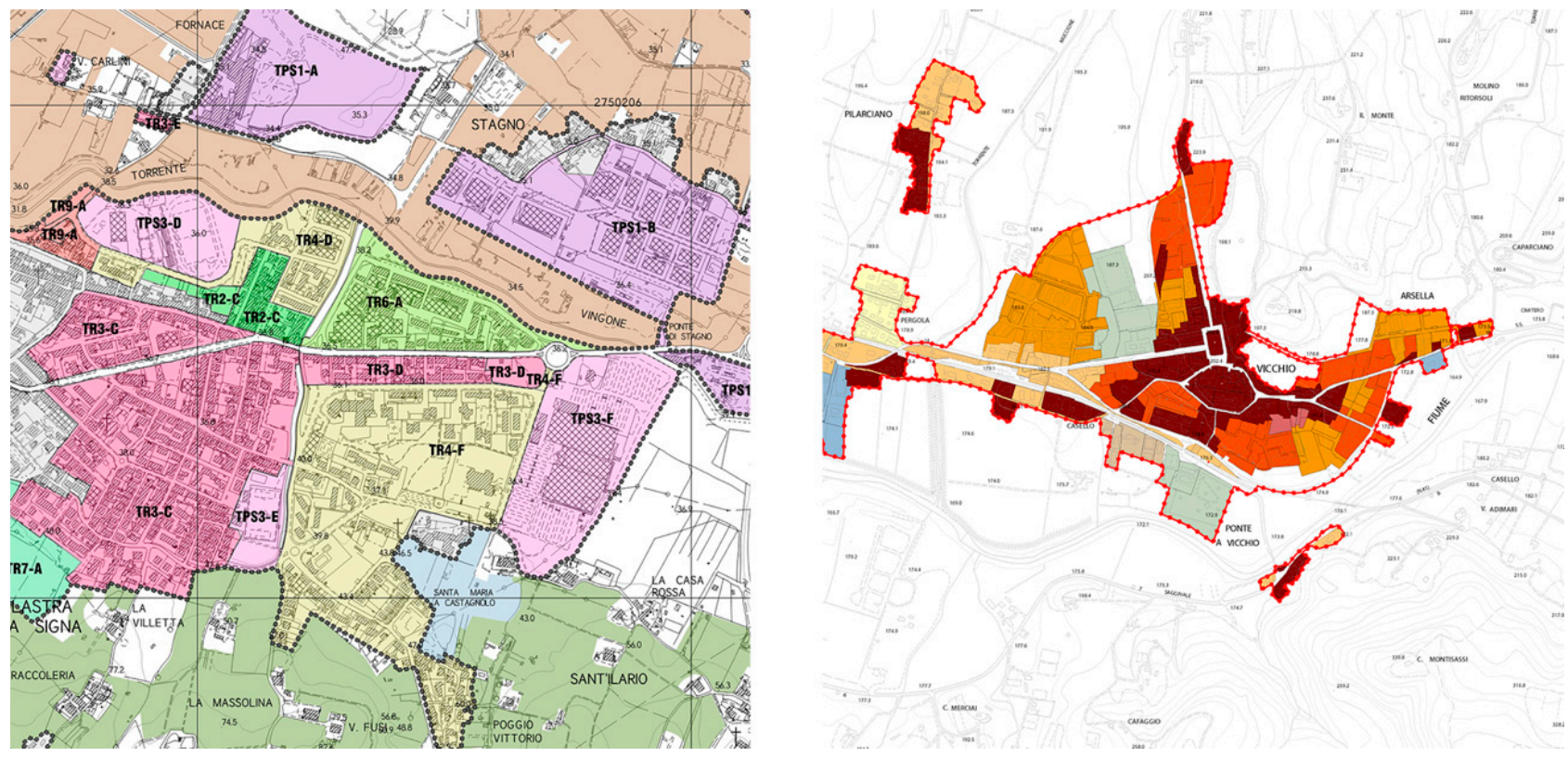

Figure 9. Mapping of contemporary urbanisation morphotypes; Lastra a Signa PS (left), Vicchio PS (right); the different colours correspond to different "morphotypes of contemporary urbanisation".

\subsubsection{Edge Redevelopment in PO Conformant with the PIT/PPR}

As we stated several times, and according to the unequivocal expression of the PIT/PPR discipline, the fundamental trait of urban fabric redevelopment regards "the design of its edges". This aspect has eminently qualitative characteristics that cannot be read analytically or schematically when compiling values in a table. However, it appears necessary to take a deeper look at this subject and the way in which urban planning tools take on this task. As previously reported, there is a conflict between two virtuous objectives that the integrated provision of the PIT/PPR with LR 65/2014 cannot resolve. On one side, there is the objective of containing land consumption by limiting settlement expansion; on the other side, the objective is to configure a new design of the urban edge by finding space within the rural territory. Let us consider this excerpt from "building materials" in the Lastra a Signa PS (Addendum and Invariant from the PIT/PPR and PTC "Urbanised territory"): "in designing the perimeter of fabrics with small size and/or density, it has sometimes proved appropriate-as indicated in the PIT/PPR and if the objectives of the related fabric so provide - to not use the actual border but to redefine it by incorporating the periurban open spaces needed to implement specific operational strategies of landscape planning in implementation of the PO according to regional guidelines". 
The conflict we are referring to sometimes provokes clear consequences in the structuring of the "story" with which the plans are proposed. In Vicchio (cf. Figure 10), the urbanised territory perimeter of the PS (approved in 4/2019) incorporates large flat cultivated areas; therefore, we must admit that they are not urbanised.
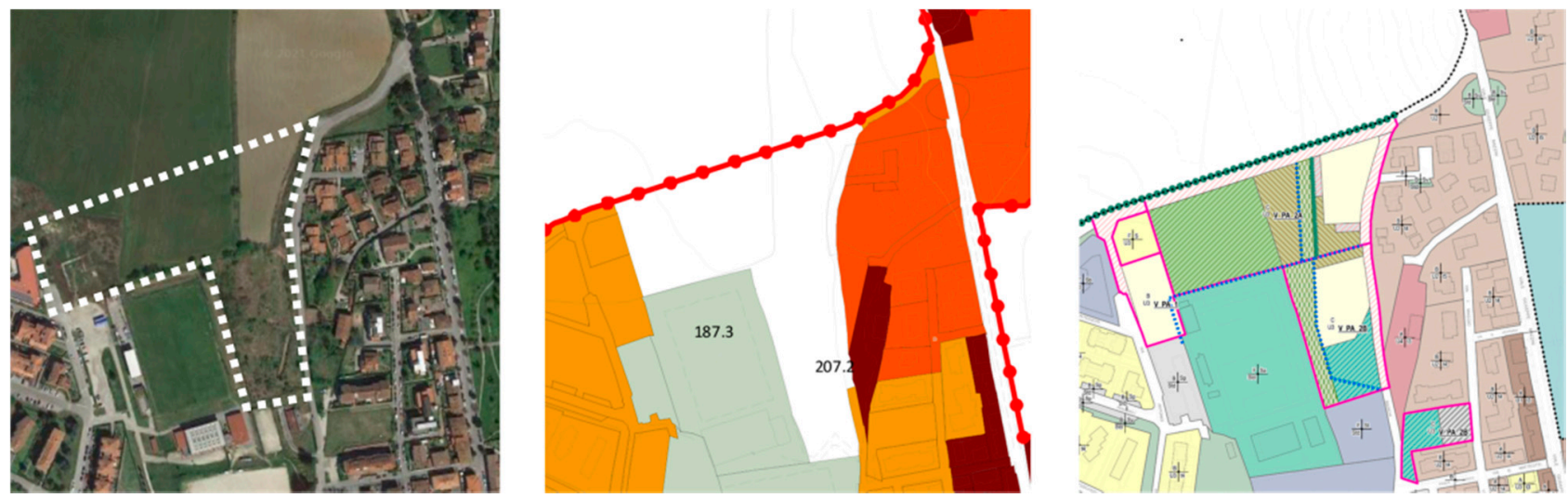

Figure 10. Actions to improve urban edges in the planning tools of Vicchio: aerial photo (left), mapping of contemporary urbanisation morphotypes in the PS (centre); map of land use rules in the PO (right). The outline in the aerial photograph indicates where soil sealing has resulted from urban edge redevelopment.

Regarding these areas, the PO (approved in 10/2019) has partially built-up transformation areas with a description that we find significant, namely "a new design of the northern border of Vicchio city centre through the creation of new public areas (sports greens, public greens and new roadways) and a new residential complex". In other words, the intervention is needed to improve the urban edge. However, the logical order of the matter, or the political agenda that motivated it, can be more effectively told in another way. The community, represented by its administration, wants to enlarge its sports areas but does not have adequate resources. To achieve this objective, it must draw on the land rent coming from the creation of a few thousand square metres of new homes. The PS contains the conditions under which it is possible to achieve this result. The PO turns this aspiration into quantitative parameters, alignments and planimetric locations. Thus, we must ask, how has the PIT/PPR - particularly the technical-operational reference of contemporary urbanisation morphotypes and the redevelopment objectives of connected urban fabricsinfluenced the local planning process in this case? The most honest and brief answer would essentially be in the language, i.e., in the rhetoric of the argumentation used by the plans, as the PIT/PPR influences language much more than transformation outcomes.

The Peccioli PO (approved in 7/2018) "confirms redevelopment of the inhabited edge on the west side of the hamlet of Fabbrica". The hamlet is located on a hill ridge that runs along a promontory facing onto the Valdera hills. The aims of redevelopment, as stated in the dedicated regulation data sheet, "have resulted from and been subject to a specific Co-planning Conference with the Region". The PO provision consists of a series of building interventions aimed at a residential development of the area, including a change of use for rural and production buildings (surface area of $2000 \mathrm{~m}^{2}$ ) and new buildings (surface area of $3740 \mathrm{~m}^{2}$ ). The interventions regard a "settlement in direct contact with the countryside, in which residual olive groves remain"; this condition has prompted the administration responsible for the PO to recognise a "strategic environment for urban redevelopment and development of the design of edges in accordance with article 4 paragraph 4 of LR 65/2014". It appears to mean that the critical condition of the urban edge that 'mingles' with the olive grove is to be 'overcome' through "transformation solutions that are strongly integrated with the agricultural context, adopting interesting models and types 'tending toward passivity' by experimenting 'with true settlement sustainability'" (...) "Thus, the PO moves away from purely urban references by experimenting solutions with 
minor impact on components of the landscape" (Peccioli PO, technical implementation standards, regulation data sheet). To summarise, these transformation solutions concern the "experimentation of architectural solutions deriving from rural tradition integrated with references to contemporary types"; adoption of "forms of passivity as integrated as possible with the scope of a design aimed at self-efficiency and eco-compatibility, including energy saving and sustainable use of resources"; and the adoption of a settlement model based on single-family dwellings on individual lots, in which the "the fence effect is as limited as possible", an objective for which "only mesh closures and gates hidden by multi-layered hedges and light structures for access systems" are acceptable for divisions between lots.

The text also contains a nod to the PIT/PPR's constant appeal to valorise the multifunctionality of peri-urban agriculture. Regarding the two plans implemented with the task of defining spatial transformation characteristics, "we can expect solutions that protect the olive groves, which can be used as green spaces open to the public or for private activities linked to the adjacent buildings".

We must ask ourselves, how does this incident—which has passed a formal conformity inspection regarding strategic planning and regional landscape at least three times-show the PIT/PPR's ability to upgrade the strategic approach and design results of local planning? It seems that we must confirm the most evident effect of the rhetoric of argumentation used to legitimise the choices. This case-due to the visual prefiguration of the 'master plan' contained in the support document regarding the Peccioli PO's conformity with the PIT/PPR (cf. Figure 11) -raises the issue of an urgent need for a clearer definition of the quality model that the Plan uses to assess the urban edge in relation to the rural territory.
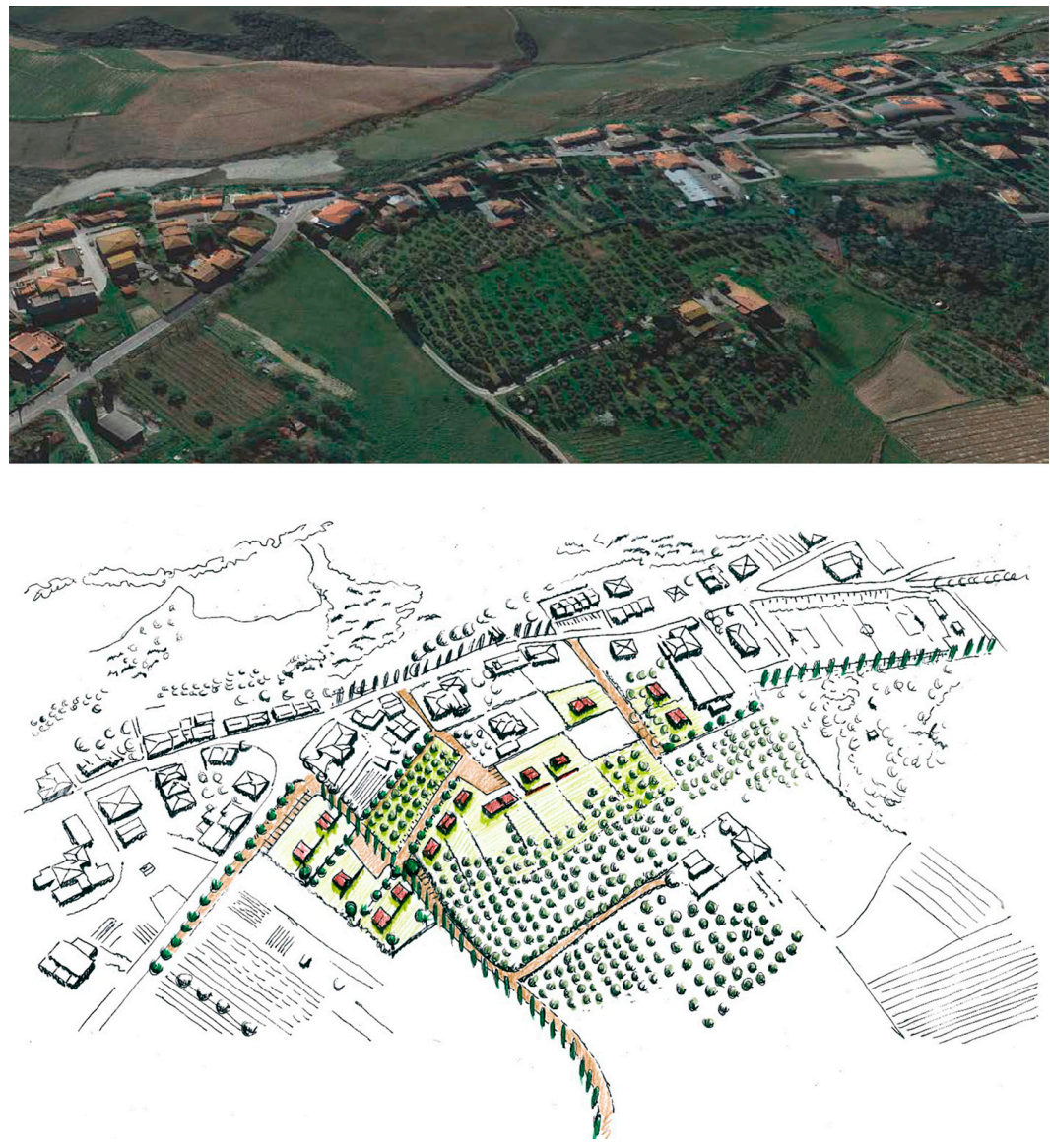

Figure 11. "Strategic framework for the improvement of the design of urban edges" (Supporting report to the conformation of the PO of Peccioli to the PIT/PPR, p. 36). The photograph above shows the current state of the hill ridge; the sketch below illustrates the urban-edge regeneration project based on new, low-density residential construction. 


\subsection{Individual Interviews with Municipal Plan Designers: Summary of Results}

The interviewed subjects (cf. par. 3.2 above) expressed a substantially positive assessment of the PIT/PPR in its entirety, especially regarding aspects linked to the interpretative reading of the regional territory and the identification of morphotypes on various scales. This richness of semantics was generally assessed as useful for the drafting of the various PS, even if at times there was much repetition in the requirements to the point of almost duplicating what had already been addressed in the PIT/PPR. Another observation was the complexity and redundancy of the language used in the PIT/PPR, which for public events-participatory phases for the drafting of the PS/PO-made the explanation of the need to adapt municipal tools to the PIT/PPR extremely difficult.

The absence of a more precise definition of the term "urban quality" in PIT/PPR materials was generally not seen as a limitation or problem, due to the common perception that the issue is extremely difficult to settle and definitions that are too strict could generate more problems for conformity and operativity than they could solve.

The most relevant issues that emerged from the individual interviews conducted with the designers, indicated in Table 4, are listed below except for the difficulty that most of the interviewees expressed regarding the many formal steps needed to obtain the approval of municipal planning tools from local offices of the Ministry of Culture Heritage, which is responsible for protecting the national landscape.

Table 4. Summary of the outcome of the interviews with the designers.

\begin{tabular}{cccc}
\hline Questions & Designer 1 & Designer 2 & Designer 3 \\
\hline & $\begin{array}{c}\text { Freelancer appointed } \\
\text { by "intermediate" }\end{array}$ & $\begin{array}{c}\text { Freelancer appointed } \\
\text { by "intermediate" and } \\
\text { municipality }\end{array}$ & $\begin{array}{c}\text { In-house design } \\
\text { manager for "belt" } \\
\text { municipality }\end{array}$ \\
\hline
\end{tabular}

Positive: appears to be a regional "structural plan", which permits identification of

Positive: especially on a "scenario" level and regarding the reading of the regional territory.

Controversy: heavy redundancy in writing of the disciplines.
Positive: good guide to territorial interpretation.

Controversy: appears dispersive, language is too specialised.
Positive: great wealth of analytical elements and useful materials for drafting PS/PO.

municipalities' tasks on a detailed scale. Appears to be a "manual" for drafting PS. Controversy: the "operational" aspect is underestimated, and morphotypes are not sufficient enough to compensate for this.

Controversy: art. 4 par. 4 of LR 65/2014 is not rigorously applied and appears to contradict PIT/PPR objectives. LR 65/2014 should indicate quantity of

B. Assessment of the PIT/PPR in conjunction with the urban planning law
Controversy: renew the PIT/PPR and LR 65/2014 together. Work in direction of Emilian model (absence of double level, quantification of land consumption). Clear work protocol between superintendency and Regione Toscana is needed. Requests by superintendencies must be standardised. consumable land (as in

Emilia Romagna) to contrast excessive land consumption dynamics. Eliminate duplication of urban planning tools, the PS is superfluous (except for several aspects of the regional area).
Positive: LR 65/2014 and PIT/PP work together sufficiently. They leave margins for Municipalities to work well "in compliance".

Controversy: limitation of land consumption linked to a demarcation "line" must be a starting point, administrations must be able to implement good planning within the densification/ expansion dialectic. 
Table 4. Cont.

\begin{tabular}{|c|c|c|c|c|}
\hline Questions & Designer 1 & Designer 2 & Designer 3 & Designer 4 \\
\hline $\begin{array}{l}\text { C. Assessment of } \\
\text { procedures } \\
\text { (Are procedures } \\
\text { needed to verify } \\
\text { urban quality?) }\end{array}$ & $\begin{array}{l}\text { Controversy: substantial } \\
\text { difficulties in managing } \\
\text { legally binding } \\
\text { regulations of the } \\
\text { Superintendency. } \\
\text { Different plans drafted } \\
\text { with similar principles } \\
\text { and criteria are assessed } \\
\text { differently by various } \\
\text { offices. Clear protocols } \\
\text { must be established. } \\
\text { Superintendencies have } \\
\text { difficulty assessing } \\
\text { planning aspects that } \\
\text { differ from } \\
\text { authorisations regarding } \\
\text { landscape assets }\end{array}$ & $\begin{array}{c}\text { Controversy: } \\
\text { procedures only } \\
\text { partially guarantee } \\
\text { quality and } \\
\text { effectiveness of the } \\
\text { PS/PO. Contingencies, } \\
\text { contexts, cultural } \\
\text { propensities and } \\
\text { supply chain } \\
\text { management have a } \\
\text { great effect. }\end{array}$ & $\begin{array}{l}\text { Positive: there were no } \\
\text { excessive problems in } \\
\text { adhering to the } \\
\text { PIT/PPR. } \\
\text { Controversy: intervene } \\
\text { in the relationship with } \\
\text { the superintendency to } \\
\text { resolve the legally } \\
\text { binding system. } \\
\text { Difficulty of the } \\
\text { superintendency to } \\
\text { work on an urban level. }\end{array}$ & $\begin{array}{l}\text { Controversy: it is a } \\
\text { serious issue that at } \\
\text { present only nine plans } \\
\text { are conformant. } \\
\text { Procedures are } \\
\text { exceptionally long. The } \\
\text { conformation } \\
\text { mechanism must be } \\
\text { totally redesigned. } \\
\text { Excessive mistrust } \\
\text { between administration } \\
\text { levels, more than in the } \\
\text { public/private } \\
\text { relationship. The } \\
\text { five-year duration is } \\
\text { useful if the office } \\
\text { is efficient. }\end{array}$ \\
\hline $\begin{array}{l}\text { D. Assessment the } \\
\text { PIT/PPR's } \\
\text { effectiveness in } \\
\text { guiding “urban } \\
\text { quality" of } \\
\text { Tuscan cities }\end{array}$ & $\begin{array}{c}\text { Positive: contemporary } \\
\text { urbanisation } \\
\text { morphotypes (CUM) } \\
\text { obligate enhancement of } \\
\text { settlement analysis } \\
\text { requested by DM } \\
\text { 1444/1968. } \\
\text { Controversy: settlement } \\
\text { morphotypes detailed } \\
\text { with CUM in the PO also } \\
\text { cause a tendency to } \\
\text { overlap areas in DM } \\
\text { 1444/1968 and the } \\
\text { CUM themselves. }\end{array}$ & $\begin{array}{l}\text { Controversy/Negative: } \\
\text { control of urban quality, } \\
\text { expressed in reference } \\
\text { to landscape but to be } \\
\text { achieved by urban } \\
\text { tools (which is } \\
\text { managed by designers } \\
\text { of the PS/PO) is } \\
\text { unlikely to be definable } \\
\text { and operable. }\end{array}$ & $\begin{array}{l}\text { Controversy: } \\
\text { everything outside the } \\
\text { urbanised territory } \\
\text { seems to have a greater } \\
\text { value than what } \\
\text { constitutes it. }\end{array}$ & $\begin{array}{l}\text { Controversy: urban } \\
\text { quality depends on a } \\
\text { multiplicity of actions } \\
\text { that are not all part of } \\
\text { planning. The } \\
\text { definition of urban } \\
\text { quality is only possible } \\
\text { throughout the entire } \\
\text { design process, } \\
\text { conformity with the } \\
\text { PIT/PPR is only the } \\
\text { first fundamental step } \\
\text { but if alone it is } \\
\text { insufficient. } \\
\text { Consider the } \\
\text { importance of the } \\
\text { public works sector. }\end{array}$ \\
\hline $\begin{array}{l}\text { E. Assessment of } \\
\text { Morphotypes (in the } \\
\text { direction of urban } \\
\text { quality) }\end{array}$ & $\begin{array}{c}\text { Positive: they are } \\
\text { generally considered } \\
\text { useful. } \\
\text { Controversy: to match } \\
\text { undeveloped areas to be } \\
\text { converted to CUM, the } \\
\text { character of nearby } \\
\text { built-up areas must } \\
\text { be used. } \\
\text { Tendency to } \\
\text { automatically indicate } \\
\text { CUM as 'planned fabrics' } \\
\text { for non-urbanised areas } \\
\text { to be transformed. } \\
\text { Prevalent use of T.R.6, } \\
\text { T.R.7 as more } \\
\text { operational tools. }\end{array}$ & $\begin{array}{l}\text { Controversy: } \\
\text { effectiveness with } \\
\text { respect to different } \\
\text { objectives is scarce. } \\
\text { Absence of "synergy" } \\
\text { between different } \\
\text { morphotypes } \\
\text { and invariants }\end{array}$ & $\begin{array}{c}\text { Positive: } \\
\text { correspondence has } \\
\text { been found despite the } \\
\text { presence of } \\
\text { non-homogeneous } \\
\text { situations in the } \\
\text { municipal territory. }\end{array}$ & $\begin{array}{c}\text { Positive: the CUM } \\
\text { device is interesting, } \\
\text { even if the territories } \\
\text { are more complex. A } \\
\text { good GRP of the past } \\
\text { could achieve this type } \\
\text { of results. } \\
\text { Controversy: calls for } \\
\text { actions on private } \\
\text { properties. } \\
\text { Regarding the PO, } \\
\text { specific knowledge of } \\
\text { an individual building } \\
\text { is needed (classification } \\
\text { and intervention class); } \\
\text { thus, the PIT/PPR } \\
\text { should encourage this } \\
\text { type of filing. }\end{array}$ \\
\hline
\end{tabular}


Table 4. Cont.

\begin{tabular}{|c|c|c|c|c|}
\hline Questions & Designer 1 & Designer 2 & Designer 3 & Designer 4 \\
\hline $\begin{array}{l}\text { F. Assessment of } \\
\text { guidelines (in the } \\
\text { direction of } \\
\text { urban quality) }\end{array}$ & $\begin{array}{l}\text { Positive: attempting to } \\
\text { address planovolumetric } \\
\text { aspects is interesting. As } \\
\text { abaci and references, } \\
\text { useful for enhancing } \\
\text { imaginary and } \\
\text { presenting } \\
\text { different solutions. }\end{array}$ & $\begin{array}{l}\text { Controversy: they raise } \\
\text { the issue of urban } \\
\text { aspects. Useful, even if } \\
\text { misleading in several } \\
\text { cases (e.g., T.R.8 } \\
\text { Linear fabric) }\end{array}$ & $\begin{array}{l}\text { Positive: use of } \\
\text { guidelines was } \\
\text { particularly intense, } \\
\text { especially for } \\
\text { verifying positive or } \\
\text { negative solutions in } \\
\text { drafting of design } \\
\text { sheets appended to } \\
\text { the PO. } \\
\text { Strengthening of this } \\
\text { tool is advisable. }\end{array}$ & $\begin{array}{l}\text { Positive: a reference to } \\
\text { guidelines was added to } \\
\text { the PO, this sometimes } \\
\text { helps to orient the } \\
\text { business of private } \\
\text { individuals. } \\
\text { Controversy: the role of } \\
\text { previsualisations is } \\
\text { delicate, the } \\
\text { "planovolumetric" } \\
\text { solution is the } \\
\text { responsibility of } \\
\text { private designers. }\end{array}$ \\
\hline $\begin{array}{l}\text { G. Assessment of the } \\
\text { PIT/PPR's } \\
\text { effectiveness in } \\
\text { elevating urban } \\
\text { margin edge quality }\end{array}$ & $\begin{array}{l}\text { Controversy: modest } \\
\text { results with respect to } \\
\text { PIT/PPR ambitions. } \\
\text { Tendency to trivialise the } \\
\text { intervention on urban } \\
\text { edges (tree rows, hedges } \\
\text { and placement of } \\
\text { drainage car parks). } \\
\text { Absence of other } \\
\text { integrated tools (PSR, } \\
\text { POR, FESSR, PNRR, etc.). }\end{array}$ & $\begin{array}{l}\text { Controversy: regarding } \\
\text { the intervention of the } \\
\text { current interpretation } \\
\text { of art. } 4 \text { par. 4, there is } \\
\text { an intrinsic weakness } \\
\text { in the possibility of } \\
\text { "improving" urban } \\
\text { edge quality due to } \\
\text { excessive } \\
\text { fragmentation of the } \\
\text { interventions. }\end{array}$ & $\begin{array}{l}\text { Controversy: } \\
\text { indications provided } \\
\text { by specific design } \\
\text { sheets drafted with } \\
\text { support from } \\
\text { guidelines for areas } \\
\text { in contact with the } \\
\text { rural territory. }\end{array}$ & $\begin{array}{l}\text { Controversy: } \\
\text { the PO, implementation } \\
\text { plans and individual } \\
\text { private projects are } \\
\text { important; however, the } \\
\text { quality of results often } \\
\text { depends on builders. To } \\
\text { manage urban edge } \\
\text { quality, every object must } \\
\text { first be known (such as } \\
\text { metal stalls), even if } \\
\text { illegal. Classification of } \\
\text { existing objects (such as } \\
\text { metal stalls) } \\
\text { must prevent } \\
\text { transformations in } \\
\text { building volumes. }\end{array}$ \\
\hline
\end{tabular}

The first relevant issue regarding the urban quality expressed by the interviewees is the effect of the integrated provision of the PIT/PPR with LR 65/2014 on the PS/PO, especially the need to identify a defined urban edge. However, their opinions were quite divergent: some (particularly external professionals appointed to design urban tools) expressed the importance of having a precise quantification of the urbanised surface to include within the limit in order to orient transformations of different territories towards urban regeneration and/or densification; others (especially internal designers from municipal offices) expressed the importance of maintaining a certain flexibility and adaptability of the edge in special and contingent situations, such as adjustment dynamics arising in the production sector or the need to add residential areas in response to an increased demand for housing.

The second issue regards the usefulness of identifying morphotypes in municipal plan tools in conformity with the PIT/PPR. The interviewees agreed that this is useful for increasing exploratory activities put in place during the drafting of tools; however, it also involves some sort of correspondence exercise that is not always useful or beneficial for the disciplines, especially when drafting the PO. Quality objectives regarding contemporary urbanisation morphotypes are difficult to achieve on a land-use planning level, including actions that involve private property and the resulting implementation difficulties.

All the interviewees agree on the third and final issue regarding the fact that the PIT/PPR can only act as an authoritative stimulus in the direction of elevating urban quality. In fact, this urban quality, in any possible variation in any of the municipalities, can only be pursued and achieved through a lucky combination of various factors. In reference to a strictly disciplinary dimension, these factors regard activities of municipal offices throughout the entire process of drafting, calibrating and monitoring the implementation of 
the PO, through continuous dialogue between private proposers and departments within the Government. Such is the case with the public works sector, due to the choices they are called upon to make and the resources that they have, who are often responsible for considerable transformations that affect urban quality and yet often work independently of municipal planning tools.

\section{Discussion}

As we initially stated, the purpose of this paper is to evaluate the effectiveness with which quality control principles for settlements and urban landscapes defined by the PIT/PPR of Regione Toscana are implemented in urban planning tools on a local scale. From this point of view, we can observe the following with regard to both the transformation of existing settlements and control of future interventions. As we stated previously, the objective of the PIT/PPR is to influence the nature and composition of urban planning tools in order to improve their ability to control urban quality. A clear example of this is the PIT/PPR's use of the concept of "morphotypes of contemporary urbanisation" as a fundamental "knowledge and technical-operational tool" for the preparation of municipal plans. As we have endeavoured to show through local case studies, the zoning method proposed by the PIT/PPR has not been able to modernise traditional techniques of identifying "homogenous territorial zones", which have been present in Italy since 1968. With respect to the innovative approach, based on the recognition and use of "morphotypes of contemporary urbanisation", called for in the PIT/PPR, many local planning tools have (1) completely ignored it, (2) used it but without sincere conviction, or (3) used it but changed the recognition criteria on the basis of their own objectives.

The limitations of the PIT/PPR as a regulatory device appear to be evident. However, we must consider that it was conceived to be both a technical tool and a descriptive narrative about the Tuscan landscape. The latter aspect is an extensive and in-depth specialistic reflection written by the Regional Councillor for Urban and Landscape Planning who was responsible for the Plan's preparation and approval—architect and professor, Anna Marson. The PIT/PPR authors also (or mostly) intended to promote a cultural action. However, immediately after its approval, the PIT/PPR was criticised by many for being oriented towards the "restoration" of an old territorial model. While not lacking in merit, these criticisms showed an inadequate understanding of the Plan's real innovative potential. In our opinion, this potential comes from envisioning landscape configurations that are both based on longue durée identity characteristics and are able to follow new development directions. This development appears consistent with the goals of social, economic and environmental innovation that were more broadly expressed by the government action of the Regione Toscana in the years that the PIT/PPR was being developed.

These goals include limiting soil consumption; curating the transition from urban to non-urban contexts; envisioning the innovative potential of rural areas; protecting peripheral and remote areas from encroaching urbanisation. As a result, the PIT/PPR inevitably appears to be a complex "narrative" and, as such, does not always adhere to the objectivity that is typical of government tools for spatial transformations. In this sense, namely through the construction of its own narrative, the PIT/PPR adopts a notion of landscape similar to that expressed in the ELC (i.e., "an area, as perceived by people"); however, in this case, it is perceived primarily by technicians and scholars. In this regard, one could make a few critical comments on the involvement of ordinary citizens in the drafting of the PIT/PPR or on the accessibility of its language.

It seems that the six years that have passed since the PIT/PPR was approved have not been sufficient to make any final conclusions about its effect on the evolution of the Tuscan landscape. In the partial and provisional assessment that we have outlined in this paper, we have identified some weaknesses in the technical tools that regulate the relationship between the regional plan (PIT/PPR) and local plans (PS or PO). However, what remains resistant in the implementation of the PIT/PPR is the power of the narrative that emerges from its comprehensive content. This narrative envisions a future for Tuscany 
that is respectful of its resources and consistent with the historical principles that shaped its evolution. It is hoped that future revisions of the PIT/PPR, which have often been called for in public debate, will be able to strengthen its weaknesses without weakening its strengths.

\section{Conclusions}

The case examined in the paper is consistently linked to the framework of rules that characterise the Italian landscape planning model. However, it is useful to see the lessons learned as an example of how to develop this approach.

Our first consideration concerns the importance of an appropriate treatment of the transition from urban to non-urban contexts. The Tuscan experience has dealt with the following epistemological question: what do we mean by landscape quality in reference to settlements and urban landscapes? As our literature review highlighted, there is a fundamental ambiguity between two definitions and two scales: in the first, the landscape quality of settlements is defined as the formal completion, recognition of edges and distinction between urban and rural domains; in the second, a high-quality urban landscape contains a number of functions that have changed over time and now include services regarding sustainability and quality of life. The Tuscan case both emphasises the first theme and shows the implications that it brings to the relationship between different planning systems. As we have observed in our examination of Italian landscape plans, particularly the Tuscan plan, the two areas of study are applied in different types of actions. The distinction between urban and rural domains is particularly used in the complex relationship between (1) rural planning and (2) policies and planning on a territorial or urban scale, usually through such laws and tools as transfer of development rights, which aim to remove buildings that are inconsistent with the character of local landscapes. In this field of action, the main issue is to find the best definition of "urban-rural edge" that can enrich contact between these two domains, often through the strategic use of multifunctional agriculture.

Therefore, with regard to settlement and urban quality, we believe that action must be taken to increase the effectiveness of landscape plans through the strengthening of interinstitutional and intersectoral governance, which can refine and improve technical devices that regulate the relationship between plans and programmes of different competencies and on different scales. As our investigation of the case study has shown, it is fundamentally important that, once a landscape plan has been approved, its implementation must be made possible through a series of regulatory and procedural tools. Otherwise, regardless of how highly innovative the plan may be, there is a risk that it will remain a political and cultural document with limited operational use.

The objectives of the Tuscan Plan are certainly present in the agendas of the administrations and institutions that have jurisdiction throughout the entire region, but we believe they are also implementable and/or being implemented throughout the rest of Italy and even Europe.

Therefore, the larger issue is which instruments and strategies can be mobilised to strengthen the effectiveness of intersectoral landscape plans on a regional scale, as their implementation is usually quite difficult, particularly in reference to the themes we have addressed in this article. These plans are also expressed as a complex "narrative" that does not entirely adhere to the objectivity of tools used to govern spatial transformations.

In this regard, we believe that one strategy that we can propose is to expand the sharing of this narrative, which has been written by a group of specialists and technicians, to include the results of a collective construction, as stated in the ELC, which emphasises the importance of people's perceptions in the recognition of a landscape. However, it is necessary to deeply reassess how citizens participate in the so-called "social production" of plans. We need to abandon the idea that "local subjectivity" and "grassroots movements" always have good intentions: an idea that presumes communities are always cohesive and that trivialises their contributions. Landscape "as perceived by the population" can be a patchwork of visions containing conflicts between various stakeholders, insiders and outsiders. In this regard, we believe that it could be important to endow the European 
Landscape Observatories with greater resources and functions so that they can effectively put into practice their competences of the knowledge, awareness and sharing of landscape values. Moreover, they could host discussion forums with technical and political parties involved in the drafting of landscape plans that focus on how to involve the population or choose the type of language to be used in plans.

Another strategy to improve the effectiveness of landscape plans with regard to quality control of settlements and urban landscapes could be to develop intersectoral policies for landscape, especially regarding urban edge redevelopment. In this area, our investigation of the case study has shown that using only urban-oriented tools is insufficient and that decisive contributions could come from rural development planning and all tools linked to community resources. These additions could go a long way in affirming the idea of sustainable economic development and respecting landscape values. There already are some integrated landscape projects that are either moving in this direction or being developed in several Italian and European regions by principled local authorities who do not see adopting a landscape plan as a mere bureaucratic conformance but are taking full advantage of the opportunity that its content has to offer. To move these experiences from being episodic to systematic, a change of perspective is needed, one that considers landscape as a public policy that (1) governs all other policies with spatial effects, (2) connects different sectoral actions and (3) integrates and makes consistent all regional policies with spatial effects.

Our assessment of what came after the approval of the PIT/PPR contributes to a reflection on the second abovementioned field of action, which sees urban landscape as a complex indicator of quality of life and can find more direct applications in the urban project field. The Tuscan case shows that it is not easy to clearly distinguish responsibilities regarding landscape planning from those regarding land-use regulations, nor the hierarchical relationship between the two fields of action.

This relationship can be complicated by different governance systems. For example, one of the clearest goals of the PIT/PPR, albeit expressed as a general orientation rather than a strict regulation, is the development of territorial policies that create a new balance in the distribution of future production sites. Such sites should be concentrated in ecologically equipped production areas on the open plain that have adequate infrastructures, thus leaving valley floors and remote areas free. This objective appears quite difficult to accomplish, as the current governance structure is not able to find transfers of development rights that can balance the economic effects of redistributing new productive sites across various municipalities.

The complexity of the relationship between the two abovementioned fields of actionlandscape planning and urban planning-needs to be managed through the development of an appropriate reflection on the technical nature and operational possibilities of planning tools. Underestimating this issue can lead to ineffective results, as is often evident in the implementation of the Tuscan plan.

Supplementary Materials: Supporting information can be downloaded at: https://www.regione. toscana.it/-/ piano-di-indirizzo-territoriale-con-valenza-di-piano-paesaggistico.

Author Contributions: Conceptualization, M.C., M.R.G. and F.L.; methodology, M.C., M.R.G. and F.L.; investigation, M.C., M.R.G. and F.L.; writing-original draft preparation: Sections 1 and 2.1 M.R.G.; Sections 2.2, 2.3, 3.1 and 4.1 F.L.; Sections 3.2 and 4.2 M.C.; Sections 5 and 6 M.C., M.R.G. and F.L. All authors have read and agreed to the published version of the manuscript.

Funding: This research received no external funding.

Institutional Review Board Statement: Not applicable.

Informed Consent Statement: Not applicable.

Data Availability Statement: Not applicable. 
Acknowledgments: The authors wish to thank the architects Daniela Campolmi, Andrea Giraldi, Lorenzo Paoli and Roberto Vezzosi for their availability and courtesy during the interviews.

Conflicts of Interest: The authors declare no conflict of interest.

\section{References}

1. Mumford, L. The Highway and the City; Secker \& Warburg: London, UK, 1964.

2. Valentini, A. Progettare Paesaggi di Limite; Firenze University Press: Firenze, Italy, 2005; ISBN 978-88-8453-407-1.

3. Muratori, S. Civiltà e Territorio; Centro Studi di Storia Urbanistica: Roma, Italy, 1967.

4. Gregotti, V. La Forma Del Territorio; Edilizia Moderna: Rome, Italy, 1966; pp. 87-88.

5. Piccinato, L. Urbanistica Medievale; Edizioni Dedalo: Bari, Italy, 1993; Volume 6.

6. $\quad$ Secchi, B. Un Progetto per L'urbanistica; Einaudi: Torino, Italy, 1989.

7. Daniels, T. When City and Country Collide: Managing Growth in the Metropolitan Fringe; Island Press: Washington, DC, USA, 1999.

8. Ahani, S.; Dadashpoor, H. Urban Growth Containment Policies for the Guidance and Control of Peri-Urbanization: A Review and Proposed Framework. Environ. Dev. Sustain. 2021, 23, 14215-14244. [CrossRef]

9. Hall, P. Cities of Tomorrow: An Intellectual History of City Planning in the Twentieth Century; Basil Blackwell: Oxford, UK, 1988; ISBN 978-0-631-13444-2.

10. Huang, D.; Huang, J.; Liu, T. Delimiting Urban Growth Boundaries Using the CLUE-S Model with Village Administrative Boundaries. Land Use Policy 2019, 82, 422-435. [CrossRef]

11. Pendall, R.; Martin, J.; Fulton, W.B. Holding the Line: Urban Containment in the United States; Center on Urban and Metropolitan Policy, the Brookings Institution: Washington, DC, USA, 2002.

12. Dierwechter, Y. Urban Growth Management and Its Discontents: Promises, Practices, and Geopolitics in US City-Regions; Springer: Berlin/Heidelberg, Germany, 2008.

13. Kaplowitz, M.D.; Machemer, P.; Pruetz, R. Planners' Experiences in Managing Growth Using Transferable Development Rights (TDR) in the United States. Land Use Policy 2008, 25, 378-387. [CrossRef]

14. Bryant, C.R.; Johnston, T.R.R. Agriculture in the City's Countryside; Pinter Press: London, UK, 1992.

15. Perrin, C.; Clément, C.; Melot, R.; Nougarèdes, B. Preserving Farmland on the Urban Fringe: A Literature Review on Land Policies in Developed Countries. Land 2020, 9, 223. [CrossRef]

16. Gottero, E.; Cassatella, C.; Larcher, F. Planning Peri-Urban Open Spaces: Methods and Tools for Interpretation and Classification. Land 2021, 10, 802. [CrossRef]

17. Donadieu, P. Campagnes Urbaines; ACTES SUD: Arles/Rennes, France, 1998; ISBN 978-2-7427-2023-1.

18. Poli, D. Agro-Urban Public Space in the European Bioregional City: The Case of the Left Riverside Agricultural Park in Florence. In Bioregional Planning and Design: Volume II: Issues and Practices for a Bioregional Regeneration; Fanfani, D., Matarán Ruiz, A., Eds.; Springer International Publishing: Cham, Switzerland, 2020; pp. 171-188; ISBN 978-3-030-46083-9.

19. Soulard, C.-T.; Perrin, C.; Valette, E. Relations between Agriculture and the City in Europe and the Mediterranean. In Toward Sustainable Relations between Agriculture and the City; Soulard, C.-T., Perrin, C., Valette, E., Eds.; Urban Agriculture; Springer International Publishing: Cham, Switzerland, 2017; pp. 1-11; ISBN 978-3-319-71037-2.

20. Mininni, M. Approssimazioni Alla Città; Donzelli Editore: Rome, Italy, 2013; pp. 1-200.

21. Golkar, K. Components of Urban Design Quality. SOFFEH 2001, 11, 38-65.

22. Golkar, K. Conceptual Evolution of Urban Visual Environment; from Cosmetic Approach through to Sustainable Approach. Environ. Sci. 2008, 5, 95-113.

23. Keshtkaran, R. Urban Lanscape: A Review of Key Concepts and Main Purposes. Int. J. Dev. Sustain. 2019, 8, 141-168.

24. Sitte, C.; Wieczorek, D. L'Arte Di Costruire Le Città. L'Urbanistica Secondo i Suoi Fondamenti Artistici; Editoriale Jaca Book: Milan, Italy, 1981; Volume 65.

25. Appleyard, D.; Lynch, K.; Myer, J.R. The View from the Road; MIT Press: Cambridge, MA, USA, 1964 ; Volume 196.

26. Cullen, G. Townscape; Architectural Press: New York, NY, USA, 1961.

27. MacHarg, I.L. Design with Nature; The Natural History Press: Garden City, NJ, USA, 1969.

28. Van der Ryn, S.; Calthorpe, P. Sustainable Communities: A New Design Synthesis for Cities, Suburbs, and Towns; Sierra Club Books: San Francisco, CA, USA, 1986.

29. Latour, B. Où Atterrir?: Comment s' Orienter En Politique; La découverte: Paris, France, 2017.

30. Coccia, E. Métamorphoses; Payot-Rivages: Paris, France, 2020; ISBN 978-2-7436-4734-6.

31. Wu, J. (Jingle) A Landscape Approach for Sustainability Science. In Sustainability Science: The Emerging Paradigm and the Urban Environment; Weinstein, M.P., Turner, R.E., Eds.; Springer: New York, NY, USA, 2012; pp. 59-77; ISBN 978-1-4614-3188-6.

32. Benson, J.; Roe, M. (Eds.) Landscape and Sustainability; Taylor \& Francis: London, UK, 2008.

33. Dinep, C.; Schwab, K. Sustainable Site Design: Criteria, Process, and Case Studies for Integrating Site and Region in Landscape Design; John Wiley \& Sons: Hoboken, NJ, USA, 2010.

34. Amin, A.M. Sustainable Urban Landscape: An Approach for Assessing and Appropriating Indicators. ArchNet-IJAR Int. J. Archit. Res. 2012, 6, 98 . 
35. Cocci Grifoni, R.; D'Onofrio, R.; Sargolini, M. The Landscape as a "Complex Indicator" of Urban Sustainability and Quality of Life of City Inhabitants. In Quality of Life in Urban Landscapes; Springer: Berlin/Heidelberg, Germany, 2018 ; pp. 11-17.

36. Gavrilidis, A.A.; Ciocănea, C.M.; Niţă, M.R.; Onose, D.A.; Năstase, I.I. Urban Landscape Quality Index-Planning Tool for Evaluating Urban Landscapes and Improving the Quality of Life. Proced. Environ. Sci. 2016, 32, 155-167. [CrossRef]

37. Council of Europe. European Landscape Convention; Council of Europe: Strasbourg, France, 2000.

38. D.Lgs 42/2004, Codice Dei Beni Culturali e Del Paesaggio. Available online: https://www.bosettiegatti.eu/info/norme/statali/ 2004_0042.htm (accessed on 30 December 2021).

39. Colavitti, A.M.; Serra, S. Regional Landscape Planning and Local Planning. Insights from the Italian Context. J. Settl. Spat. Plann. 2021, 7, 81-91. [CrossRef]

40. Ministero dei Beni e delle Attività Culturali e del Turismo. Pianificazione Paesaggistica—Quadro Sinottico: Aggiornamento Giugno 2021; Technical Report; Italian Ministry: Roma, Italy, 2021.

41. Magnaghi, A. (Ed.) La Pianificazione Paesaggistica in Italia; Firenze University Press: Firenze, Italy, 2016; Volume 26, ISBN 9788864533711.

42. Di Pietro, R.; Perrone, F.; Del Re, N.; Franzosi, M.; Natalia, M.C.; Pellegrino, P.; Penna, E.; Peroni, E.; Tolli, M.; Trusiani, E. A Survey of Landscape Planning in Italy, Where Application Is Utopia. An Updated Proposal for a Shared Landscape Analysis Model. Plant Sociol. 2019, b56, 113-128.

43. Ministero dei Beni e delle Attività Culturali e del Turismo, Osservatorio Nazionale per la qualità del paesaggio. Rapporto Sullo Stato delle Politiche per Il Paesaggio; Gangemi: Roma, Italy, 2017.

44. Carta Nazionale Del Paesaggio. Elementi per Una Strategia per Il Paesaggio Italiano; Ministero dei Beni e delle Attività Culturali e del Turismo, Osservatorio Nazionale per la qualità del paesaggio, Ed.; Gangemi: Roma, Italy, 2018.

45. Gisotti, M.R. Il Piano Paesaggistico Alla Prova Del Governo Del Territorio: Verso Un Modello Di Pianificazione Regionale Integrata. CRIOS 2018, 16, 65-76. [CrossRef]

46. Ministero dei Beni e delle Attività Culturali e del Turismo. Atto Di Indirizzo Concernente L'individuazione Delle Priorità Politiche Da Realizzarsi Nell'anno 2021 e per Il Triennio 2021-2023; Technical Report; Italian Ministry: Roma, Italy, 2021.

47. Gambino, R. Interpretazione Strutturale e Progetto Di Territorio. In Contesti. Città Territori Progetti; 2010; Volume 2, pp. 71-76. Available online: https:/ / didattica.polito.it/pls/portal30/gap.pkg_guide.viewGap?p_cod_ins=01UTWPW\&p_a_acc=2022\&p_ header=S\&p_lang=\&multi=N (accessed on 30 December 2021).

48. Magnaghi, A. Le Invarianti Strutturali, Fra Patrimonio e Statuto Del Territorio. In La Struttura del Paesaggio. Una Sperimentazione Multidisciplinare per il Piano della Toscana; Marson, A., Ed.; Laterza: Bari, Italy, 2016.

49. Fanfani, D.; Perrone, C. Progetti Territoriali per Il Paesaggio: Livelli e Strumenti Del Progetto Paesaggistico Del PIT. Progetti Territoriali per Il Paesaggio: Livelli e Strumenti del Progetto Paesaggistico del PIT; Firenze University Press: Firenze, Italy, 2012 ; pp. 63-74.

50. Pascolini, M. Beyond the Norm: The Strategic Part of the Regional Landscape Plan of Friuli Venezia Giulia. Ri-Vista 2019, 18, 40-49. [CrossRef]

51. Albrechts, L.; Barbanente, A.; Monno, V. Practicing Transformative Planning: The Territory-Landscape Plan as a Catalyst for Change. City Territ. Archit. 2020, 7, 1. [CrossRef]

52. Gabellini, P. La Norma Figurata Nel Piano Urbanistico Contemporaneo. In L'innovazione del Piano. Temi e Strumenti Urbanistici a Confronto; Cinà, G., Ed.; F. Angeli: Milano, Italy, 1996.

53. Valentini Il Paesaggio Figurato: Disegnare le Regole per Orientare le Trasformazioni; Firenze University Press: Firenze, Italy, 2018; ISBN 978-88-6453-683-5.

54. Moroni, S.; Lorini, G. Graphic Rules in Planning: A Critical Exploration of Normative Drawings Starting from Zoning Maps and Form-Based Codes. Plann. Theory 2017, 16, 318-338. [CrossRef]

55. Regione Piemonte Indirizzi per La Qualità Paesaggistica Degli Insediamenti. Buone Pratiche per La Pianificazione Locale; Piano Paesaggistico Regionale. Direzione Regionale programmazione strategica, politiche territoriali ed edilizia, DIPRADI (Dip. di Progettazione Architettonica e di Disegno Industriale-Politecnico di Torino), 2010. Available online: https://www. regione.piemonte.it/web/sites/default/files/media/documenti/2018-11/buonepratichepianificazionelocale.pdf (accessed on 30 December 2021).

56. Regione Piemonte Indirizzi per La Qualità Paesaggistica Degli Insediamenti. Buone Pratiche per La Progettazione Edilizia; Piano Paesaggistico Regionale. Direzione Regionale programmazione strategica, politiche territoriali ed edilizia, DIPRADI (Dip. di Progettazione Architettonica e di Disegno Industriale-Politecnico di Torino), 2010. Available online: https://www. regione.piemonte.it/web/sites/default/files/media/documenti/2018-11/buonepraticheprogettazioneedilizia.pdf (accessed on 30 December 2021).

57. Regione Piemonte Linee Guida per l'analisi, La Tutela e La Valorizzazione Degli Aspetti Scenico-Percettivi Del Paesaggio; Piano Paesaggistico Regionale. Direzione Programmazione strategica, politiche territoriali ed edilizia, MiBACT (Direzione Regionale per i beni culturali e paesaggistici del Piemonte), DIST (Dipartimento Interateneo di Scienze, Progetto e Politiche del Territorio-Politecnico di Torino/Università degli Studi di Torino), 2014. Available online: https:/ /www.regione.piemonte.it/ web/sites/default/files/media/documenti/2018-12/lineeguida.pdf (accessed on 30 December 2021).

58. Regione Puglia. Linee Guida Sulla Progettazione Di Aree Produttive Paesaggisticamente Ed Ecologicamente Attrezzate. In Piano Paesaggistico Territoriale Regionale; 2015; Available online: http:/ / paesaggio.regione.puglia.it/PPTR_2015/4_Lo\%20scenario\%20 strategico/4.4_Linee\%20guida/4.4.2_linee\%20guida\%20aree\%20produttive.pdf (accessed on 30 December 2021). 
59. Regione Puglia Linee Guida per Il Patto Città Campagna: Riqualificazione Delle Periferie e Delle Aree Agricole Periurbane. In Piano Paesaggistico Territoriale Regionale; 2015; Available online: http://paesaggio.regione.puglia.it/PPTR_2015/4_Lo\%20 scenario\%20strategico/4.4_Linee\%20guida/4.4.3_Patto\%20citta\%27\%20campagna.pdf (accessed on 30 December 2021).

60. Bonneau, E. Interpret the Landscape as a Project the Tuscan Bioregionalist Contribution to Territorial Planning. Geo-Regards 2015, 8, 39-53.

61. Carta, M. The Landscape Plan of the Tuscan Region (Italy): Identification, Role and Project of the in-between Spaces; UAUIM: Bucarest, Romania, 2016; pp. 550-560.

62. Cambi, F.; Salzotti, F. Archeologia, storia e processi di territorializzazione. In La Struttura Del Paesaggio. Una Sperimentazione Multidisciplinare per Il Piano Della Toscana; Marson, A., Ed.; Laterza: Bari, Italy, 2016.

63. Lucchesi, F. L'evoluzione Della Rappresentazione Georeferenziata Dei Caratteri Territoriali. In La Struttura del Paesaggio. Una Sperimentazione Multidisciplinare per il Piano della Toscana; Marson, A., Ed.; Laterza: Bari, Italy, 2016; pp. 101-113.

64. Poli, D.; Rossi, M.; Morisi, M. Il Paesaggio Nel Governo Del Territorio; Firenze University Press: Florence, Italy, 2018. 